\title{
Meşrutiyetin Üç Halkçılığı ve Kemalist Halkçılığa Etkileri
}

\author{
Yard. Doç. Dr. Evren Haspolat ${ }^{*}$
}

\section{$\ddot{O} z e t$}

Halkçllk gerek bir hareket olarak gerekse düşünce olarak II. Meşrutiyet aydınının gelişimi ile birlikte Türk düşünce dünyasına girmiştir. Düşünsel köklerini ă̆ırlıkl olarak Rus Narodnik Hareketi'nden alan Meşrutiyet Halkçılığl, 1- Ziya Gökalp Halkçıllğ̆, 2- Halka Doğru Cemiyeti Halkçılı̆̆ ve 3-Yusuf Akçura Halkçılı̆̆ olmak üzere ü̧̧ farkl yönelim üzerinden gelişmiştir. Kemalist Halkçıllk ise Meşrutiyet Halkçıllğı'nın birikimi üzerinde yükselmiş ve onun özellikle Gökalp ve Akçura yönelimlerinden önemli ölçüde etkilenmiş, onlardan güçlü izler taşımıştır. Ancak bu izler aynı oranda da Fransız Devrimi'nin Üçüncü Sinıf anlayışına yaklaşmış ve ulusal birlik-bütünlük anlamındaki dayanışma anlayışı ile harmanlanarak yeni ve kendine özgü bir halkçıllk anlaylşı olarak belirmişstir. Bu anlamda Kemalist Halkçıllk, ulus ve ulus devlet inşası sürecinin dayandı̆ğ en temel ittifak siyaseti olarak belirmiştir.

Anahtar Kelimeler: 1- Halkçılık, 2- Kemalist Halkçılı, 3- Ziya Gökalp Halkçıllğ̆l, 4- Halka Doğru Cemiyeti Halkçıllğı, 5-Yusuf Akçura Halkçıllğ̆l.

\section{Three Populısm of the Constitutional Monarchy and Their Effects on Kemalist Populism}

\begin{abstract}
Both as a movement and as a thought, Populism entered to the Turkish world of thinking with the development of Second Constitutional Revolution's intellectuals. Constitutional Monarchy Populism's roots can be found in the Russian Narodnik Movement and it developed in a three distinct way: 1- Populism of Ziya Gokalp, 2-
\end{abstract}

* Ordu Üniversitesi, Kamu Yönetimi Bölümü. 
Towards the People Committee's Populism and 3- Populism of Yusuf Akçura. Kemalist Populism was built upon the historical heritage of the Constitutional Monarchy Populism and it was affected particularly from Gökalp's and Akçura's way of thinking. However these signs came close to the Third Class understanding of the French Revolution by the same degree and it was mixed with the solidarity thought connecting national unity-integrity and producing a new and original understanding of populism. In this sense, Kemalist Populism came to the scene as the most fundamental unity policy in the course of nation and nation state building.

Key Words: 1- Populism, 2- Kemalist Populism, 3- Ziya Gökalp's Populism, 4Towards the People Committee's Populism, 5- Yusuf Akçura's Populism.

\section{Giriș}

II. Meşrutiyet Türk düşünce tarihinde bir dönüm noktasına denk düşer. O güne kadar belli aydınlar arasında sınırlı düzeyde ve özellikle II. Abdülhamit'in İstibdat Dönemi'nde gizlilik içinde yayılan farklı düşünce akımları, Kanunu Esasi’nin II. Meşrutiyet ile birlikte yeniden yürürlüğe konulduğu koşullarda özgürce ifade olunmaya başlamış ve matbuatın anayasa ile serbest bırakıldığı ortamda yayınlar aracılığ kesimlere erişme olanağı bulmuştur. $\mathrm{Bu}$ anlamda gerek Osmanlı'da Meşrutiyet Dönenimde etkisini gösterecek olan düşünce akımları, gerekse Osmanlı üzerinden Cumhuriyet'e miras kalan düşünce akımlarının hemen tümü II. Meşrutiyet'in yarattığı özgürlük ortamında gelişme ve yayılma firsatı bulmuştur. Halkçılık düşüncesi de tıpkı diğer düşünce akımları gibi II. Meşrutiyet'in yarattığ 1 bu düşünce ikliminde Türk düşünce tarihine girmiş ve gelişmiştir. Yine bir düşünce akımı olarak halkçıllı̆ın ilk yönelimleri de bu dönemde belirginleşmiş.

Temel olarak Rus Narodnik Akımı'ndan köklerini alan Meşrutiyet Halkçılığı, ortaya koyduğu temel farklılıklar nedeniyle Ziya Gökalp Halkçılığı, Halka Doğru Cemiyeti Halkçılığı ve Yusuf Akçura Halkçılığ olarak ifade edilebilecek olan üç temel yönelim üzerinden ilerlemiş ve Cumhuriyet Dönemi Halkçılı̆̆ ya da Kemalist Halkçılık olarak ifade edebileceğimiz halkçılık anlayışını da bu yönelimlerin inşa ettiği birikim üzerinden etkilemiştir. Bu anlamda bu makalede temel olarak Meşrutiyet Halkçılı̆̆ı'nın Kemalist Halkçılığa etkileri irdelenmiş ve bu irdeleme de Meşrutiyet Halkçıllı̆̆ı'nın tespit edilen üç temel yönelimi üzerinden yapılmıştır. Bu çerçevede makalede öncelikle Türk Halkçılığı'nın Narodnik kökenleri incelenmiş, ardından II. Meşrutiyet Dönemi'nde ileri sürülen farklı halkçılık görüssleri incelenmiş ve bunlar aralarındaki temel farklar üzerinden üç ayrı halkçılık anlayışı/yönelimi olarak ayrıştırılmış, ardından da bunların 
Kemalist Halkçılığa etki düzeyleri değerlendirilmiştir. Çalışma bu değerlendirmelerden elde edilen çıkarımların yer aldığı sonuç bölümü ile tamamlanmıştır.

\section{Türk Halkçılığının Narodnik Kökenleri}

Zafer Toprak'ın "İkinci Meşrutiyet aydınının can simidi” olarak tanımladığ1 halkçılık düşüncesi, Jön Türk ${ }^{2}$ geleneğinin bütün elitistliğine rağmen, Abdülhamit rejimine karşı halkı yanına almak gibi bir tutumun giderek kendisini dayattığ 1 bir dönemde -bu anlamda biraz da zorunluluktan, Türk siyasal düşünce evrenine girmiştir ${ }^{3}$. Bu nedenle Osmanlı'da halkçı1lığın ortaya çıkması, doğrudan doğruya yeni bir aydın sınıfı olarak Jön Türklerin ortaya çıkması süreciyle paralellik gösterir ${ }^{4}$. Çünkü Karaömerlioğlu'nun da belirttiği gibi,

"Köhnemiş (ancien) siyasal rejimler, içsel nedenler bir yana, özellikle uluslararası sistemde varlıklarını sürdürebilmek için modernleşme sürecini kendi elleriyle ve de yeni bir aydın kesimi yaratarak çelişik bir şekilde yaşarlar... Modernleşmenin doğrudan bir ürünü olarak gündeme gelen aydınlar modernleşme sürecini hızlandırmak ve mantıksal sonucuna ulaştırmak isterken sık sık köhne devlet aygıtlarıyla çatışmaya girmişlerdir... Devletle olan mücadeleleri radikalleştikçe de halkı yanına alma gereksiniminin arttı̆̆ 1 ve aydınların daha radikal çözümlere yöneldikleri görülür. Bu noktada halkçı düşüncelerin serpilip gelişmesinde yeni bir aydın tipolojisinin doğması merkezi bir rol oynar"s.

Dolayısıyla Osmanlı'da halkçılık düşüncesi Meşrutiyet aydınının bir yönelimi olarak ve onunla birlikte doğmuştur. Çünkü onun önceli olan Tanzimat'ın Batılılaşmış aydını toplumcu değil, bireyciydi ve onlar

${ }^{1}$ Zafer Toprak, “Aydın, Ulus,-Devlet ve Popülizm”, Türk Aydını ve Kimlik Sorunu, Der. Sabahattin Şen, Bağlam Yayınları, İstanbul, 1995, s. 39.

2 “Avrupa'da, gerek I. Meşrutiyet için çalışan Namık Kemallerin kuşağına, gerekse II. Meşrutiyet için çalışanlara Jön Türk denildiği halde, Türkiye'de Jön Türk deyince daha çok $1889^{\prime}$ dan sonraki dönemde, II. Meşrutiyet için çaba gösterenler anlaşılmaktadır. İlk devrimci kuşak ise Türkiye'de daha çok Yeni Osmanlılar diye tanınmaktadır (bazı yazarlar Genç Osmanlılar da demektedirler). Tunaya, Yeni Osmanlılar hareketine, Avrupa'da Jön Türk denilmiş olmasından hareketle, 1889'dan sonraki akım için, İkinci Jön Türk hareketi deyimini de kullanmıştır" (Sina Akşin, Jön Türkler ve İttihat ve Terakki, İmge Yayınevi, Ankara, 2001, s. 26). Ben de Jön Türkleri II. Meşrutiyet için çalışan aydınları ifade etmek üzere kullanıyorum ve makale boyunca yeri geldiğince de kendilerini 'Meşrutiyet aydını' olarak ifade edeceğim.

${ }^{3}$ M. Asım Karaömerlioğlu, "Tek Parti Döneminde Halkçılık”, Modern Türkiye'de Siyasi Düşünce, Cilt-2: Kemalizm, İletişim Yayınları, İstanbul, 2002, s. 273.

${ }^{4}$ Karaömerlioğlu, a.g.e., s. 273.

${ }^{5}$ Karaömerlioğlu, a.g.e., s. 273. 
açısından Batı'nın modern uygarlığı ile aydınlatılacak olanlar toplum değildi, yalnızca kişilerdi. Yine bu dönemin aydınlarına göre devletin gerileyen gücünü yeniden tesis etmek ve 'devleti kurtarmak' için yapılması gereken şey de yalnızca Batı'nın tekniğini almaktı. Bu anlamda Tanzimat döneminde hem tekniğin toplumla olan ilişkisi hem de toplumla birlikte bir iş yapılması gerektiği henüz kimsenin aklına gelmiyordu ${ }^{6}$. Dolayısıyla halka gitmek ve halka yaslanarak devleti kurtarmak düşüncesinin ve hareketinin gelişmesi için gerekli olan maddi ve düşünsel zemin Tanzimat'ın yapay Batıcılık ikliminde yoktur. Ve söz konusu zemin ancak II. Meşrutiyet ile birlikte biçimlenecektir. Halka yaslanarak kurtulma düşüncesinin maddi zeminini Balkanlar'daki ayrılıkçı/ulusalcı hareketlerin yol açtığı büyük toprak kayıpları oluştururken (1860'lardan itibaren), bu maddi gerçeklik karşısında aydın/yönetici kesimin "devleti nasıl kurtarırız?" sorusuna yanıt ararken iflas eden/tutmayan Osmanlıcılık ve İslamcılık aşıları karşısında Rus Narodnik Hareketi'nden etkilenmesi de halkçılık düşüncesinin düşünsel zeminini oluşturacaktır.

$\mathrm{Bu}$ anlamda halkçılık düşüncesi Meşrutiyet aydınının 'ideolojisi' olduğu gibi, düşünsel kaynağını da Rusya' da 1870'lerden itibaren gelişen bir akım olarak Narodnik Hareketi'nden (popülizm, halkçılık) alır. 'Halka gitme' şiarı nedeniyle 'halka doğru gidenler' hareketi olarak bilinen Narodnizm'in kökleri ise Herzen ve Çernişevski'nin 1800'lerin ilk yarısında ileri sürdüğü görüşlere dayanmakla birlikte, bir siyasal akıma dönüşmesi 1868 y1lında Bakunin'in Narodnoye Delo (Halkın Davas1) Dergisi'nde yayınlanan bir makalesinde genç Ruslara üniversiteleri bırakıp 'halka gitme' çağrısı yapması ile söz konusu olur ${ }^{7}$. Halkçıllk düşüncesi, kapitalizmin kendisinden beklenen ilerici rolü yerine getiremediği fikrinin yaygınlaşttğ 1 1870'lerde gelişmiş ve temelde burjuva demokratik radikalizmi ile bir sistem olarak kapitalizme karşı çıkışı bir araya getiren bir akım olmuştur ${ }^{8}$. Halkçılık, Walicki'nin belirttiği gibi 'ilk 'halka gitme' akımının destekleyicilerinden sonra ortaya çıan ve öteki devrimci çizgilerden 'kitlelerin eğitimli seçkinler üzerinde hegemonyası'nı savunmasıyla ayrılan bir eğilimi anlatmak için kullanılır. Sözcüğün bu anlamında 'popülizm', köylülerden bir şeyler öğrenmek yerine, onlara öğretmeye kalkan ve gerçek

${ }^{6}$ Niyazi Berkes, Batıcılık, Ulusçuluk ve Toplumsal Devrimler, Kaynak Yayınları, İstanbul, 2002a, s. 40-43.

${ }^{7}$ Andrzej Walicki, Rus Düşünce Tarihi -Aydınlanma'dan Marksizme-, Çev. Alaeddin Şenel, İletişim Yayınları, İstanbul, 2009, s. 344. Ayrıca, Rus düşünce tarihinde halkçı düşüncenin gelișimi ve köklerinin ayrıntılı bir incelemesi için yine Walicki'nin anılan eserinin "Rus Sosyalizminin Kökenleri”, "Nikolay Çernişevski ve 1860'ların Aydınlatıcıları" ve "Popülist İdeolojiler" bölümlerine bakılabilir.

${ }^{8}$ Walicki, a.g.e., s. 342. 
çıkarları konusunda neler söyleyip neler yapabileceklerini dinlemek yerine, köylülere Batı sosyalizminin ideallerini dayatmaya çalışan devrimcilerin 'soyut entelektüelcilik' eğilimlerine karşı çıkan bir akımdı. Savunulan savaşım yöntemleri bakımından da... yalnızca halk arasında, halk kanalıyla eylemi savunmaktaydılar" ". Söz konusu anlayış ve eylem biçimi ile ortaya çıkan Rus Halkçılığı, toprağını her geçen gün zengin çiftçilere kaptıran ve bu yüzden giderek yoksullaşan küçük üretici köylülüğe sahip çıkmış, devrimin gerçekleşmesi için de onları Çarlığa karşı başkaldırıya çağırmıştır. Bu koşullarda köylülügü kazanmak için Rus aydınına biçilen görev de halka gitmek, halkı uyarmak, eğitmek ve aydınlatmak olarak saptanmıştır ${ }^{10}$.

$\mathrm{Bu}$ içeriği ile "Çarlık Rejimi'ni devirmek ve ülkeyi kurtarmak için köylüleri ayaklandırmayı hedefleyen" Halkçılık Akımı başarıya ulaşamasa da Rusya'daki toplumsal mücadeleyi 1885 yılına kadar etkileyen ana akımlardan birisi olmuştur ${ }^{11}$. Ancak etkileri itibariyle Rus Halkçıllı̆ı yalnız Rus siyasal düşününü etkilemekle kalmamış, Rusya ile benzer sosyoekonomik özellikler taşıyan, yani henüz kapitalistleşmemiş imparatorluk coğrafyalarını da etkileyen önemli bir siyasal akım olmuştur. Ki bunlardan birisi de Osmanlı Devleti'dir ve Rusya'daki halkçılık akımının Türk aydınlarına üç ayrı yol üzerinden etki ettiği bilinmektedirr ${ }^{12}$. Bunlardan ilki, Balkan ve özellikle Bulgar aydınları iken; ikincisi, Rusya'dan gelen Türklerdir. Dolaylı yolu oluşturan üçüncü yol ise Ermeni aydınlarının başlattığı ve nasyonalist Taşnak hareketinden ayrı olan sosyalist Hınçak hareketidir; çünkü bu ikincisi Narodnik fikirlerinin etkisi altında doğmuştur ${ }^{13}$.

Osmanlı Devleti'nde aydınlar ve bürokrasi Tanzimat Dönemi'nden beri devletin kötü gidişatını engellemek ve 'devleti kurtarmak', 'ayakta tutabilmek' için çeşitli görüşlere yönelmiştir. Tümü 'devleti nasıl yaşatırız?'

\footnotetext{
${ }^{9}$ Walicki, a.g.e., s. 341-342.

${ }^{10}$ Toprak, a.g.e., s. 41.

11 Arda Odabaşı, "İlk Türk 'Halka Doğru Gitme' Eylemi ve İlk 'Halka Doğru Gidenler,', Teori Dergisi, (Ocak 2007), s. 40-55; Veysel Yıldız, "Rusya'da Halkçılığın Doğuşu ve Gelișimi”, Teori Dergisi, (Eylül 2005), s. 44-48.

${ }^{12}$ Türk Halkçılığı, Rus Halkçılığı'ndan etkilenmiş olmakla birlikte onun kaba bir taklidi veya birebir benzeri değildir, kendi toplumsal gerçekliği tarafindan belirlenmiştir. Çünkü Türkiye'de de özellikle 20. yüzyılın başından itibaren halkçılık için uygun bir sosyoekonomik ortam oluşmuştur. Bu bağlamda Rus ve Türk halkçılıklarının benzerlikleri ve farklılıkları için bkz. Arda Odabaşı, "2. Meşrutiyet Dönemi Türk Halkçılı̆̆ı ve Halka Doğru Dergisi”, Teori Dergisi, Eylül 2005, s. 9-27.

${ }_{13}$ Berkes, 2002a, s. 81-82. Zafer Toprak da Osmanlı Halkçılarının söz konusu kanallar üzerinden halkçılık düşüncesi ile tanıştığını belirtir ve bu çerçevede özellikle Rus Narodnik Akımı'nın Balkanlar'daki uzantısı olan "halkçılık (popülizm)" ve "köylücülüğün (peasantism)"etkisine değinir (Toprak, a.g.e., s. 41).
} 
sorusuna/sorununa birer yanıt/çözüm olarak gelişen bu düşüncelerin ilki olan Tanzimatçı Batıcılık, zaten Meşrutiyet aydınları tarafından reddedilmiş ve bu anlayışa tepki olarak Osmanlıcılık, İslamcılık, Halkçılık ve Türkçülük ${ }^{14}$ gibi düşünceler geliştirilmiştir. Bunlardan Osmanlıcılık ve İslamcılık henüz II. Meşrutiyet öncesinde -1904 yılında-, Yusuf Akçura'nın kaleme aldığı “Üç Tarz-1 Siyaset" başlıklı makalede "Osmanlı Devleti'ne yararı ve uygulanabilirliğì" biçimindeki "iki temel ölçütün 1şığında" ayrıntılı olarak incelenmiş ve Akçura tarafından her iki görüş de gerçekçi temellerden

\footnotetext{
${ }^{14}$ Her ikisi de II. Meşrutiyet Dönemi'nde gelişen Türk Halkçıllı̆ı ve Türk Milliyetçiliği iç içe geçmiş bir gelişim çizgisi izlemiş ve dahası Türk Milliyetçiliği Türk Halkçılı̆̆ı'nın içinden doğarak gelişmiştir. Berkes'in belirttiği gibi "bugün bizde hangi edebiyat kitabını açsanız orada Meşrutiyet'le birlikte bir milliyetçilik ve milli edebiyat akımı başladığ 1 iddiasını görürsünüz. Halkçıllk ve toplumculuk hareketlerinden hiç söz etmezler. Hâlbuki gerçek olan şudur: Milli edebiyat akımı ve milliyetçilik, halkçılık hareketinden sonra ve onun hücumlar karşısında aldığı şekil olarak doğmuştur” (Berkes, 2002a, s. 83). Bu anlamda II. Meşrutiyet milliyetçiliği asıl olarak halkçıdır (Odabaşı, 2007, s. 53). Öyle ki Türk Milliyetçiliği'nin önde gelen isimlerinden Ziya Gökalp bile "Ulusal Kurtuluş Savaşı'na kadar, gerçek anlamıyla milliyetçi değil, Osmanlıcıdır. Milliyetçiliği, o dönemde, sadece bir 'mefkure' (ideal) olarak anlar ve bunu Türk aydınının halkçılık, yani Türk toplumunu kalkındırma davasında girişeceği siyasi ve kültürel çabalarda bir ölçü, bir yön verici olarak ileri sürer" (Berkes, 2002a, s. 83-84). Gökalp'in kendi ifadesi ile "Türkçülükle halkç1lığın sonunda aynı gündemde birleşmeleri, ikisinin de gerçeğe ve gerçekliğe uymasının bir sonucudur. İkisi de tam gerçeği buldukları içindir ki, tamamıla birbirine uydular. Bu özdeşliğin bir sonucu da şudur ki, bütün Türkçülerin, hiçbir istisnası olmamak üzere, Anadolu savaşına katılmaları ve onun en ateşli savunucuları olmalarıdır. Türkiye'de Tanrı'nın kılıcı, halkçıların elinde ve Tanrı'nın kalemi, Türkçülerin elindeydi. Türk yurdu tehlikeye düşünce, bu kılıçla bu kalem evlendiler; bu evlilikten bir toplum doğdu ki, adı Türk Ulusu'dur. Gelecekte de, her zaman Halkçılıkla Türkçülük el ele vererek ülküler dünyasına doğru birlikte yürüyeceklerdir. Her Türkçü, siyaset alanında halkçı kalacaktır; her halkçı da, kültür alanında Türkçü olacaktır... 'Siyasetteki yolumuz, halkçılık ve kültürdeki yolumuz, Türkçülüktür'” (Ziya Gökalp, Türkçülüğün Esasları, Yay. Haz. Kemal Bek, Bordo Siyah Yayınları, İstanbul, 2003, s. 236237). Bu nedenle Türk düşününde Halkçılık Türkçülüğü öncelediği gibi, Türk Milliyetçiliği de çıkış itibariyle halkçıdır. Ancak Berkes’in belirttiği gibi Türk Halkçılığı "peykçi Batıcılar, Osmanlıcılar, İslamcılar, yani bütün alafranga aydınların, halkçılara hakaret veya alay kastıyla 'Türkçü' adını takmaları" ile birlikte "yavaş yavaş Türkçülük-milliyetçilik-kavmiyetçilik olarak tanınmaya başlamış”tır. "Halkçılar, bu kavramlarda pişmiş adamlar değillerdi: çoğu ordudan ayrılmış pratik genç subaylardı. Daha kendilerine gelemeden, içlerine karışan başka bir unsur hem bunların halkçılığını bozmaya, hem halkçıların düşmanlarına hak verdirecek fikirleri sokuşturmaya başladı. Bu unsur, halkçıların Osmanlı Türkiye'si ve Türk halkıyla ilgilenişleri zıddına, Rusya'daki Müslümanların milliyet davasıyla ilgili olan Rusya göçmeni aydınlardı... Türkiye'ye sığınan göçmen aydınlar arasında milliyetçilik, Tatarcılık ile Türkçülük arasında gidip gelen bir ırkçılık şeklinde kendini gösterdiği gibi, Türkiye'deki halkçılardan farklı olarak bunlarda kuvvetli bir burjuvazi anlayışı vardı... Bu, halkçılık hareketini gelişme imkânından mahrum ettikten başka, onu halkçılık hareketini gelișme imkânından mahrum ettikten başka, onu halkçılık davasından ayrılan bambaşka bir şekle, hatta 1rkçılık veya bir pan hareketi haline sokma imkânlarını taşıyordu. Türkiye'deki halkçılık hareketi, böylece kendini bir alay mayın tarlası içinde buldu" (Berkes, 2002a, s. 86-87).
} 
yoksun bulunarak başarısız siyasetler olarak tespit edilmiştir ${ }^{15}$. Çünkü Akçura'ya göre "Osmanlı milletini, Osmanlı ülkelerindeki bütün kavimlerin arzusu hilafına, harici manilere rağmen, Osmanlı hükümetinde işbaşında bulunan birkaç kişi, bazı Avrupa devletlerine (bilhassa Üçüncü Napolyon Fransa'sina) dayanarak meydana getirecekti”, ki bu anlamda Osmanlıcılik düşüncesinin başarı şansı "pek az muhtemeldi"16. Yine İslamcılık da Akçura'ya göre “İslam'ın menfaati, Osmanlı Devleti'nin ve Türklüğün menfaatlerine tamamen uymadı̆̆ı" için Osmanlı'nın faydasına değildi ${ }^{17}$. Akçura'nın düşünsel düzeyde ileri sürdüğü bu tespitler, anılan düşüncelerin hayata geçirilmesi sürecinde gerek Balkanlar'da gerekse İslam coğrafyasında karşılaşılan ayrılıkçı/ulusalcı hareketler ile de maddi temelde doğrulanmıştır.

İşte tam da Osmanlıcılık ve İslamcılığın gerçeklikten uzak birer 'kurtuluş yolu' olduğu belirginleşirken, Rus Halkçıllı̆̆'ndan etkilenen bir grup aydın, kurtuluşun ancak halk ile birlikte ve ona ulaşılarak mümkün olabileceği düşüncesi ile farklı kanallardan ve farklı 'yollarla' "halka gitme"ye başlamış ve böylece Türk halkçılığının temeline ilk harcı koymuşlardır. Bu bağlamda Türk Halkçıları, Türk Ocağı ve Milli Talim ve Terbiye Cemiyeti çevresinde toplanmış, Köylü, Türk Yurdu ve Halka Doğru gibi dergileri çıkarmıştır" ${ }^{18}$. Bu anlamda "halka doğru gitme" hareketi öncelikle dergiler ve gazeteler aracılığı ile basın-yayın alanından başlatılmıştır. Öyle ki İzmir'de 21 Ağustos 1908 'de yayın hayatına başlayan Köylü Gazetesi'nin amacı "açık yazar, okuyanı yormaz, vatanın faydasına çalışır" olarak ifade edilirken, "Köylü'nün özellikle 'Köylülerin mektebi' olduğu vurgulanmakta ve herkese sade bir dille hizmet götürmeye çalıştığ da belirtilmektedir". Yine Arıkan'ın belirttiği üzere Köylü'nün "kullandığ 1 yalın Türkçe, köye ve köylüye yönelik yayınları, gazetenin çıkış amaçlarına bağlı kaldığını kanıtlamaktadır. Üstelik bu gazete köylere muhabirler göndermiş, köylülerin sorunlarını yansıtmak için büyük çaba harcamıştır"19.

Yine Köylü'nün halkı tanıma çabasının bir benzeri Dr. Şerafettin Mağmuni Bey’den (Bilmen) gelmiştir. Mağmuni, 1890'larda yaşanan kolera salgını sırasında müfettiş olarak gittiği Anadolu'daki gözlemlerini içeren anılarını önce Tercüman-1 Hakikat Gazetesi'nde yayınlatmış, ardından ise Seyahat Anıları -Anadolu ve Suriye'de- başlığı ile 1909'da Kahire'de kitap

\footnotetext{
${ }^{15}$ François Georgeon, Türk Milliyetçiliğinin Kökenleri: Yusuf Akçura 1876-1935, Çev. Alev Er, Tarih Vakfı Yayınları, İstanbul, 2005, s. 34.

${ }^{16}$ Yusuf Akçura, Üç Tarz-1 Siyaset, Lotus Yayınları, Ankara, 2008, s. 53-54.

${ }^{17}$ Akçura, a.g.e., s. 47.

${ }^{18}$ Toprak, a.g.e., s. 41.

19 Zeki Arıkan, "Tanzimat ve Meşrutiyet Döneminde İzmir Basını", Tanzimat'tan Cumhuriyet'e Türkiye Ansiklopedisi, 1. Cilt, İletişim Yayınları, İstanbul, 1985, s. 107.
} 
olarak yayınlatmıştır. Bu anı kitabının ardından edebiyatın Anadolu'ya yönelmesinin ilk örneği de 1910 yılında Ebubekir Hazım Bey'in (Tepeyran) Küçük Paşa romanı ile verilmiştir. 1914 yılında da Ahmet Şerif Bey'in 1909-1914 yılları arasındaki Anadolu gezi notları Tanin Gazetesi'nde “Anadolu'da Tanin" başlığı altında yayınlanmıştır. Bu dönemde Edirne, İzmir, Kayseri, İzmit, Adapazarı gibi pek çok ile ilişkin gezi yazıları da kaleme alınmıştır. Bu yazılardan ikisi de Türk Yurdu Dergisi'nde yayınlanmıştır. Bunların ilki 1913 yılında Şehabettin Süleyman Bey'in "Anadolu ve Gençliğin Vazifesi" başlıklı makalesinin bir kısmı iken, bir diğeri de 1916 yılında yayınlanan Ispartalı Hakkı Bey'in "Köyümden Geliyorum" başlıklı yazı dizisidir ${ }^{20}$.

Anadolu'ya yapılan bu geziler ve gezilere dayanan izlenim yazılarından özellikle son ikisi, halka gitme konusunda 'gençliğe' yönelen çağrıları içeren yazılardır. Bu çerçevede Türk Halkçılığı'nın ilk 'halka doğru gitme' hareketi de 1913 yılının Temmuz ayında bir grup Tibbiyeli genç tarafından başlatılmıştır. İki ay süresince İzmir ve çevresinde gezinen gençler izlenimlerini ilk olarak 27 Eylül 1913’te “Anadolu'da Yaya Seyahati Hatıraları-1" başlı̆ğ ile Tasvir-i Efkâr Gazetesi'nde yayınlamış, ardından da 2 Ekim 1913'te Halka Doğru Dergisi'nde yazının bir kısmı yeniden yayınlanmıştır. İkinci 'halka doğru gitme' hareketi de yine bir doktor olan Dr. Reşit Galip Bey'in önderliğinde 1919 yılında gerçekleşmiştir. Dr. Reşit Galip de tıpkı ilk halka doğru hareketini gerçekleştiren Tıbbiyeli gençler gibi köylere giderek, halkın arasına karışarak hem onlara sağlık götürmek hem de halkı bizzat içinde tanıyarak dertlerine çare bulmak gerektiğine inanmış bir aydındır ${ }^{21}$.

\section{İkinci Meşrutiyet'in Üç Halkçılığı}

Yukarıda belirtildiği gibi Rus Narodnik Akımı'nın Osmanlı aydınları arasındaki etkileri II. Meşrutiyet ile birlikte başlamış ve yine ilk örneklerini de -gerek düşünsel gerekse de eylemsel boyutta- bu dönemde vermiştir. Halkçılık akımının gelişimine ilişkin olarak bir 'zemin etüdü' olarak değerlendirilebilecek olan bu ilk atılımlar, ilerleyen dönemde inşa edilecek olan Cumhuriyet Halkçılığının/Kemalist Halkçılığın da temelini oluşturmuştur. $\mathrm{Bu}$ dönemde ortaya çıkan halkçılık akımı yekpare bir bütün olmayıp, kendi içinde birbirlerinden belirli noktalarda farklılaşan yönelimleri barındırır. Bu yönelimleri 1- Ziya Gökalp Halkçılığı, 2- Halka Doğru

\footnotetext{
${ }^{20}$ Odabaş1, 2007, s. 41-44.

${ }^{21}$ Odabaş1, 2007, s. 46-53. İlk halka doğru gitme eylemleri ve ilk halka doğru gidenler hakkında ayrıntılı bir çalışma için bkz. Odabaşı, 2007.
} 
Cemiyeti Halkç11ığı ve 3- Yusuf Akçura Halkçıllı̆̆ olarak üçe ayırmak doğru olacaktır.

Halk sözcügünün dillerde yerleştiği ve o günkü anlamı itibariyle "ulus ya da millet sözcüğüyle eşanlamlı kullanıldığı” II. Meşrutiyet Dönemi'nde, halkçılık sözcüğü de ilk kez Ziya Gökalp tarafından kullanılmıştır ${ }^{22}$. Gökalp Halkçılığı'nın da diğer halkçı yönelimler gibi ilk esin kaynăg 1 Rus Narodnizmi'dir. Gökalp "Halka Doğru” başlıklı makalesinde Türkçülüğün ilk esaslarından birisinin 'halka doğru' ilkesi olduğunu belirttir ve halka yönelmenin gerekçesini de makalesinde son derece açık bir biçimde ortaya koyar: "Artık yüzlerce ulustan birleşen yapay toplulukların sürmesine olanak kalmamıştır. Bundan sonra, her ulus ayrı bir devlet olacak; kaynaşmış, içten, doğal bir toplum hayatı yaşayacaktır"23. İşte bu nedenle halka doğru gitmek gerekmektedir. Peki halka doğru gitmek ne demektir ve halka doğru gidecek olanlar kimlerdir? Bu soruya Gökalp'in verdiği yanıt şudur:

"Seçkinler yüksek bir öğrenim ve eğitim görmüş olmakla, halktan ayrılmış olanlardır; işte halka doğru gitmesi gerekenler bunlardır. Seçkinler halka doğru niçin gidecekler?... Seçkinlerin neyi vardır? Halkta ne vardır? Seçkinlerin, uygarlığı vardır. Halkta kültür. Öyleyse, seçkinlerin halka doğru gitmesi şu iki amaç için olabilir: 1- Halktan kültürel bir eğitim almak için, halka doğru gitmek; 2- Halka uygarlık götürmek için, halka doğru gitmek"24.

Görüldüğ̈̈ üzere Gökalp'e göre artık devir ulus devlet olma devri olduğu içindir ki halka doğru gitmek ve bir taraftan ondan ulus bağını kuracak olan halk kültürünü alırken, diğer taraftan da ona uygarlık aşılamak gerekmektedir. Söz konusu bu ilişkinin tarafları olan aydın ile halk arasında ise Gökalp'e göre "sınıfsal esaslı bir ayrım yoktur" 25 . Aydın yalnız eğitimli olması ile halktan ayrılır. Ki gözlemlenen bu ayrım da 'güzideler' halka gidince ortadan kalkacaktır ${ }^{26}$. Halkı ile arasında yalnız eğitimli olmasından ötürü bir fark bulunan aydının görevi, halka giderek ondan kültürü almak ve eğitim ile edindiği uygarlık bilgisini de ona taşımaktır. Halk ile aydın arasındaki bu alışveriş ile yani halka doğru gitmekle kaynaşmış, doğal bir toplum hayatı kurulabilecek, yaşanan yıkım aşılarak devlet ve halk kurtulacaktır.

\footnotetext{
${ }^{22}$ Toprak, a.g.e., s. 40.

${ }^{23}$ Gökalp, 2003, s. 82.

${ }^{24}$ Gökalp, 2003, s. 79-80.

${ }^{25}$ Tekeli, İlhan; “Türkiye'de Halkçılık”, Cumhuriyet Dönemi Türkiye Ansiklopedisi, 7. Cilt, İletişim Yayınları, İstanbul, 1983, s. 1930.

${ }^{26}$ Tekeli, a.g.e., s. 1930.
} 
Halka doğru hareketinin yöneleceği özne olarak halkın ve bu anlamda halkçılık düşüncesinin neyi ifade ettiğini ise Gökalp Yeni Mecmua'nın 14 Şubat 1918 tarihli 32. sayısında yayınlanan "Halkçılık" başlıklı makalesinde ortaya koymaktadır. Gökalp anılan makalesinde, dünya savaşının 'halkçılık' ve 'milletçilik' ülkülerinin şiddetlenmesine ve değer kazanmasına neden olduğunu belirttikten sonra, sosyal tabakalar itibariyle toplumların semiyye, kast, tarik (meslek), derebeylik, sinıf ve meslek devri olmak üzere altı aşamadan geçtiklerini belirtir ${ }^{27}$. Bu aşamalardan beşincisi olan 'sınıf devri'nin Osmanlı Türkiyesi'nde Tanzimat Dönemi'ne karşılık geldiğini belirtir ve bu aşamada halkçılık için iki büyük adım atıldığına değinir. Gökalp'e göre:

"Tanzimat, bir tarafdan raiyyeliğ $\mathrm{i}^{28}$ diğer cihetden de zimmiliğ $\mathrm{i}^{29}$ ilga ederek halkçılığa doğru iki büyük adım atdı. Bu adımlar, Ayan'ların iktisab etmiş olduğu asalet ve hürriyet sıfatlarının ve memleketin umumi idaresinde rey vermek haklarının aşağıdaki diğer tabakalara da teşmilinden ibaretdi. Zaten demokrasi, bütün halkın aristokrat olması demektir. Tanzimat'la Meşrutiyet herkesi siyasi sınıflarda eski Ayan derecesine çıkardı... Yeni devrede, 'avam' namı verilen kitle, Ayanlarla müsavi olunca 'halk' namını ald1... Binaenaleyh Türkiya' da artık ecnebilerle mezhebi cemaatlerden başka siyasi imtiyazlara malik birtakım tabakalar kalmamışdı. Harici ve dahili kapitülasyonların ilgası bu imtiyazları da ref etdiğinden bugün Türkiya'nın siyasi noktai nazardan tamamiyle demokratik yani halkçı bir cemiyet olduğunu iddia edebiliyoruz"30.

Bu anlamda Gökalp'e göre Tanzimat, hem kapitülasyonları hem de Osmanlı sınırları içerisinde yaşayan farklı dinsel gruplar arasındaki ayrıcalıkları kaldırarak alt sınıfları ayan ile eşitlemiş, böylece siyasal açıdan halkçı bir toplum kurmuştur. Bu dönemde 'avam', artık ayanla eşit konuma gelerek 'halkı' oluşturmuştur. "Ona göre sınıf ve eğitim farkı gözetmeksizin herkes, kişilerin kanun önünde eşitliğini kabul koşuluyla, halktan biridir"’31. Dolayısıyla Gökalp'te halk, her şeyden önce hukuksal ve bu bağlamda siyasal düzlemde bir eşitlenmeye denk düşer ki bu ona göre Tanzimat

\footnotetext{
${ }^{27}$ Ziya Gökalp, “Halkçılık”, Teori Dergisi, (Ocak 2007), s. 56-62.

${ }^{28}$ Raiye: Sakl, mahfuz, korunup gözetilmiş.

${ }^{29}$ Zimmi: Anlaşma ile İslâm diyarında yaşaması kabul edilmiş, hayatı hıfzedilen (korunan) gayr-1 müslim.

${ }^{30}$ Gökalp, 2007, s. 61-62.

31 Uriel Heyd, Türk Ulusçuluğunun Temelleri, Çev. Kadir Günay, Türkiye Cumhuriyeti Kültür Bakanlığı Yayınları, Ankara, 2002, s. 62. Heyd'in ifadesi ile Gökalp "bu tanımlamaya dayanarak, aristokrasi ve feodal asilleri halkın dışında tutmakta ve aydınları ve orta sınıfı herhangi bir özel ayrıcalık talep etmedikleri sürece halktan saymaktadır” (Heyd, a.g.e., s. 62).
} 
Dönemi’nde yapılanlar ile mümkün olabilmiştir. Altıncı aşama olan meslek devrinde ise Gökalp'e göre,

“... siyasi tabakalar kalmamakla beraber, birtakım iktisadi tabakalar yine mevcuttur. Bu iktisadi tabakalara sınıf namı verilir. Bu sınıflar 'büyük eşraf', yani 'büyük burjuvazi', 'küçük eşraf', yani 'küçük burjuvazi' ile gündelikçilerdir. İște bugün 'içtimai halkçılık' namı da verilen 'solidarizm' hareketi, eski devirlerdeki siyasi tabakalar gibi bu iktisadi sınıfların da izâlesine çalışıyor. Siyasi halkçılık herkesi siyasi hukuk itibariyle Ayan'lar derecesine çıkarmıştı. İçtimai halkçılık ise herkesi terbiyevi ve iktisadi mazhariyetler cihetiyle eşrafa müsavi yapmak istiyor. Halkçılığın esası, cemiyet içinde 'semiyye, kast, tarik, ocak, sınıf' diye birtakım inhisarcı yahut imtiyazlı zümre ve tabakaların bulunmamasıdır. Halkçılık, ayırıcı zümreler yerine, cemiyetin fertlerini biribirine sık1 rabitalarla birleştiren meslek zümrelerinin kaim olmasına çalışıyor. Çünkü, cemiyet içtimai bir uzviyete benzetilirse, bu uzviyetin birer hayati vazife ifa eden hakiki uzuvları ancak meslek zümreleri olabilir. Bundan dolayıdır ki cemiyetler tekâmül ettikçe iş bölümü ve ihtisas müesseseleri gittikçe derinleşiyor ve mesleki teşkilatlar gittikçe daha sıkı bir tesanüd, daha büyük bir ehemmiyet kazanıyor... İşte bu muharebenin kuvvetlendirdiği iki mefkûreden birisi, mesleki teşkilatların hâkimiyetine istinad eden bu siyasi ve içtimai halkçılıktır"’32.

Gökalp sınıf aşamasında siyasal düzlemde herkesin eşitlenerek halkı oluşturduğunu belirttikten sonra, 'içtimai halkçılık' olarak ifade ettiği son aşamada da var olan iktisadi tabakaların (sınıflar) kaldırılacağını ve böylece siyasal eşitliğin ardından iktisadi ve terbiyevi düzeyde de eşitliğin sağlanacağından söz etmektedir. Zaten ona göre halkçılığın esası, toplum içerisinde kast, ocak, sınıf gibi birtakım tekelci ya da ayrıcalıklı zümre ve tabakaların bulunmamasıdır. Bu anlamda Gökalp'te halkçılık tam olarak, siyasal düzlemde eşit oy hakkına sahip olan ve iktisadi düzlemde ise meslek teşkilatlarının hakimiyetine dayanan dayanışmacı bir toplum anlayışına denk düşer. Dolayısıyla Gökalp Halkçılığı'nda toplum, sınıfsal çelişkiler ve çatışmalardan azade, dayanışma temelinde işbölümüne göre örgütlenen 'kaynaşmış' bir halk olarak tanımlanır.

Gökalp'in halk, halkçılık ve halka doğru gitme anlayışları birlikte değerlendirildiğinde, halkı "ulusu oluşturan hammadde" olarak gördüğü anlaşılmaktadır ${ }^{33}$. Dolayısıyla Gökalp Halkçılığı, halkçılık ile Türkçülüğü

${ }^{32}$ Gökalp, 2007, s. 62.

${ }^{33}$ Heyd, a.g.e., s. 62. 
(ulusçuluğu/milletçiliği) birbirini bütünleyen olmazsa olmazlar olarak değerlendirir. Gökalp'in ifadesi ile:

"Türkçülükle halkçılığın sonunda aynı gündemde birleşmeleri, ikisinin de gerçeğe ve gerçekliğe uymasının bir sonucudur. İkisi de tam gerçeği buldukları içindir ki, tamamıla birbirine uydular. Bu özdeşliğin bir sonucu da şudur ki, bütün Türkçülerin, hiçbir istisnası olmamak üzere, Anadolu savaşına katılmaları ve onun en ateşli savunucuları olmalarıdır. Türkiye'de Tanrı'nın kılıcı, halkçıların elinde ve Tanrı'nın kalemi, Türkçülerin elindeydi. Türk yurdu tehlikeye düşünce, bu k1lıçla bu kalem evlendiler; bu evlilikten bir toplum doğdu ki, adı Türk Ulusu'dur. Gelecekte de, her zaman Halkçılıkla Türkçülük el ele vererek ülküler dünyasına doğru birlikte yürüyeceklerdir. Her Türkçü, siyaset alanında halkçı kalacaktır; her halkçı da, kültür alanında Türkçü olacaktır... 'Siyasetteki yolumuz halkçılık ve kültürdeki yolumuz Türkçülüktür'”34.

"Siyasetteki yolumuz halkçılık ve kültürdeki yolumuz Türkçülüktür". Gökalp Halkçılığı’nın özeti tam da bu cümlede saklıdır. Siyaset halka hizmet için halka yönelecek, yani halkçı olacak ve bu halkçı siyasal yönelim kültürel düzeyde Türkçülük ile bütünlenecektir.

Meşrutiyet Halkçılığı'nın, Gökalp Halkçılı̆̆g'ndan sonraki ikinci yönelimi Halka Doğru Cemiyeti Halkçılığı'dır. Gökalp'in aristokrasi ve feodal asilleri dişarıda tutarak, aydınları ve orta sınıfı herhangi bir özel ayrıcalık talep etmedikleri sürece halktan sayan daha genel halk anlayışının aksine, 1. Dünya Savaşı ile birlikte halk sözcüğünün içeriğini farklı bir içerik ile biçimlendiren bir yönelim de gelişmiştir. Bu dönemde Taşra İttihatçıları, halkı artık 'orta sınıf' olarak görmeye ve uluslaşma sürecinde orta sınıfın öncülüğünü benimsemeye başlamışlardır ${ }^{35}$.

Bu doğrultuda en ilginç gelişme de Osmanlı Devleti’nin uluslararası sermaye ile en erken ve en çok bütünleşmiş kenti olan İzmir'de izlenmiştîn ${ }^{36}$. İzmir 18. yüzylldan itibaren Doğu Akdeniz'in en büyük liman kenti olurken, aynı zamanda da tüm Osmanlı İmparatorluğu'nun bir yandan Batı ile ve diğer yandan ise Pers ve Uzakdoğu ile ticaretinin en önemli limanı olarak

\footnotetext{
${ }^{34}$ Gökalp, 2003, s. 236-237.

${ }^{35}$ Toprak, a.g.e., s. 47.

36 İzmir'in Osmanlı'nın uluslararası sermaye ile en erken ve en çok bütünleșen kenti olmasının yerel ve uluslararası nedenleri/boyutları için bkz. Orhan Kurmuş, Emperyalizmin Türkiye'ye Girişi, Yordam Yayınları, İstanbul, 2008; Reşat Kasaba, Osmanlı İmparatorluğu ve Dünya Ekonomisi, Çev. Kudret Emiroğlu, Belge Yayınları, İstanbul, 1993.
} 
görülmekteydi ${ }^{37}$. Dolayısıyla İzmir 18. yüzyılda elde ettiği "imparatorluğun uluslararası limanı statüsü" ile "ticari düzlemde, Batılı ekonomiler ile Osmanlı İmparatorluğu içinde bir yeniden-dağıtım merkezi olarak belirmişti”38. Ancak İzmir Osmanlı’nın en önemli liman kenti olmakla birlikte, kent ticaretine ve dolayısıyla sermayeye hâkim olanlar hem Osmanlı'da ticaretin gayrimüslimlerin 'kadim hakkı' olması hem de İzmir' in son derece kozmopolit bir yapıya sahip olması nedeniyle ağırlıkla Rumlar ve Ermenilerdi. Ancak bu durum İttihat ve Terakki'nin kesin olarak iktidara geldiği ve iktisadi Türkçülüğü uygulamaya koyduğu 1913 y1lından itibaren hızla değişmiştir. Önce Girit sorunu, daha sonra da Balkan Savaşları Rumların elindeki işletmelerde bir boykot hareketine neden olmuş, bunu ise 1910, 1911 ve 1913 yıllarında Müslümanlara ait sermayeyle bankalar ve şirketlerin $^{39}$ kuruluşu izlemiştir ${ }^{40} .1913$ yılında İttihat ve Terakki Cemiyeti’nin İzmir sekreterliğine Mahmut Celâl Bey (Bayar) ve yine aynı yıl içinde İzmir valiliğine de yine Cemiyet'in önemli isimlerinden Rahmi Bey atanmıştır. Celâl Bey özellikle Rum ve Ermenilerin elinde olan ticaret, sanayi ve ulaşım şirketlerini Türklere tahsis ederken, Rahmi Bey de İzmir Ticaret ve Sanayi Odası'nın yapısına Türkler lehine el atmakta ve 1914'te İslam Tüccar ve Esnaflarına Mahsus Rehber gibi Müslüman tüccarların işyeri bilgilerini içeren rehberlerin yayınlanmasına önayak olmaktaydı ${ }^{41}$.

\footnotetext{
${ }^{37}$ Alp Yücel Kaya, “19. Yüzyıldan 21. Yüzyıla İzmir Ekonomisinde Süreklilik ve Kırılmalar”, Değişen İzmir'i Anlamak, Der. Deniz Yıldırım-Evren Haspolat, Phoenix Yayınevi, Ankara, 2010, s. 51; Elena Frangakis-Syrett, "Uluslararası Önem Taşıyan Bir Akdeniz Limanının Gelişimi: Smyrna (1700-1914)”, Çev. Işık Ergüden, İzmir 1830-1930 Unutulmuş Bir Kent Mi? -Bir Osmanlı Limanından Hatıralar-, Der. Marie-Carmen Smyrnelis, İletişim Yayınları, İstanbul, 2008, s. 27.

38 Marie-Carmen Smyrnelis, “Öndeyiş: Tarihini Arayan Şehir”, Çev. Işık Ergüden, İzmir 1830-1930 Unutulmuş Bir Kent Mi? -Bir Osmanlı Limanından Hatıralar-, Der. Marie-Carmen Smyrnelis, İletişim Yayınları, İstanbul, 2008, s. 12.

${ }^{39}$ Aydın Kooperatif İncir Müstahsilleri Anonim Șirketi, İzmir İthalat ve İhracat Türk Anonim Şirketi, İzmir Teshilat Şirketi, Milli Aydın Bankası, Manisa Bağcılar Bankası, Türkiye Palamutçuları Anonim Şirketi ve İzmir İmarat ve İnşaat-1 Umumiye Şirketi'nin kuruluşunu bu çerçevede değerlendirmek gerekir. Bkz. Erkan Serçe, "II. Meşrutiyet Döneminde İzmir", Değişen İzmir'i Anlamak, Der. Deniz Yıldırım-Evren Haspolat, Phoenix Yayınevi, Ankara, 2010, s. 39.

40 Stefanos Yerasimos, Azgelişmişlik Sürecinde Türkiye -Bizans'tan 1971'e-, Çev. Babür Kuzucu, Gözlem Yayınları, İstanbul, 1980, s. 624.

${ }^{41}$ Serçe, a.g.e., s. 37. Akçura, İttihat ve Terakki'nin kendi sermayedarını yaratmasının gerekliliğini ve önemini şöyle ifade etmektedir: "Eski İttihatçı memurin-i askeriye ve mülkiyenin sahib-i sermaye olmasıyla, fırkanın da demokratik çeşnisi hemen hemen zail olmuştu. Lakin hükümeti elde tutmak, memlekete hakikaten hâkim olabilmek için, yalnız bu kuvvetler kafi değildi. Diğer kuvva-yı içtimaiyeye dayanmak zarureti vardı. Bahusus, memurin sınıfı, metin, sabit ve emin bir sınıf sayılamazdı. Bunun içindir ki İttihad ve terakki Fırkası, Memalik-i Osmaniye'de bütün Türk ashab-1 emlak ve akarının ve Müslüman erbab-1
} 
Yerel düzeyde Celâl ve Rahmi beylerin uygulamalarına ek olarak Osmanlı Hükümeti de merkezi düzeyde "1914 y1lı Ağustos ayından başlayarak, 'İzmir'deki bütün yabancı kuruluşlardan, bütün Rum görevlilerin işlerinden çıkarılarak yerlerine Müslümanların alınmasını ister" ${ }^{42}$ ve yine 1916 yılında aşar fazlası olarak alınan vergilerin Ege'de köylüye terk edilmesi uygulaması ile köylünün sermayesi arttırılmış olur ${ }^{43}$. İşte gerek merkezi gerekse yerel boyuttaki bu uygulamalar Eşref Kuş̧̧ubaşı'nın belirttiği gibi 'İzmir'in millileştirilmesi daha açık tabiriyle Gâvur İzmir'in Türk İzmir olabilme fetih hareketi, bütün memlekete şamil bir hayat davası mahiyetini" alması ile söz konusu olmuştur ${ }^{44}$. Ve bu anlamda İzmir iktisadi Türkçülük politikasının bir tür pilot uygulama alanı olmuştur ki yarattığg sonuçlar dikkate alındığında da oldukça başarılı bir uygulamadır. Çünkü söz konusu uygulama Osmanlı İmparatorluğu'nun dünya ekonomisi içindeki konumunda bir değişiklik yaratmamakla birlikte, ülke içi güç ilişkilerinde yarattığı dönüşüm ile gayrimüslimleri ekonomik etkinliklerin dışına itmiş, böylece de Müslüman bir burjuvazi/orta sınıf yaratılmasının olanaklarını sağlamıştır ${ }^{45}$.

Ekonomik alanda bir Müslüman-Türk orta sınıfı yaratma girişimi ekonomik düzeyde Celâl Bey ve Rahmi Bey'in yukarıda belirtilen girişimleri çerçevesinde yürütülürken, siyasal düzeyde de bu girişimi bütünleyecek adımlar yine aynı isimlerin önderliğinde atılmıştır. 15 Aralık 1917'de İzmir'de Tarık Zafer Tunaya'nın ifadesi ile "İttihat ve Terakki'nin gölgesinde kurulan" Halka Doğru Cemiyeti bu açıdan önemli bir oluşumdur. Derneğin kurucuları eski Halep valilerinden Tevfik Bey, İzmir mebusu ve eski valisi Rahmi Bey, Dr. Nazım Bey ve Celâl Bey'dir' ${ }^{46}$. Bu anlamda 'orta sınıf' ağırlıklı bir Halka Doğru Cemiyeti’nin İzmir'de kurulması bir rastlantı

ticaretinin kabiliyet-i iktisadiyelerini arttırarak ve bunların rukba-yı iktisadiyesinin iktidar rekabetlerini tahdid ederek, menafi-i iktisadiyelerini inkişaf ettirmek istedi... Harbin sonlarına doğru, İttihad ve Terakki Fırkasına Türk burjuvazisinin mümessilidir, demek hatalı olmaz" (Yusuf Akçura, "İttifak'a Dair", Siyaset ve İktisat, Yay. Haz. Erdoğan Mura, Sinemis Yayınları, Ankara, 2006a, s. 16).

${ }^{42}$ Yerasimos, a.g.e., s. 625.

${ }^{43}$ Toprak, a.g.e., s. 49. Toprak'ın İttihat ve Terakki'nin merkez yönetiminden Doktor Nazım Bey'in 1917 yılındaki bir demecinden alıntılandığına göre "Akhisar'da aşar fazlası olarak alınan \% 12 geçen sene köylüye terk edilmiş ve ahali bu parayı sermaye ittihaz ederek bir köylü bankası açmışlardır” (Toprak, a.g.e., s. 49).

${ }^{44}$ Kutay 1999'dan aktaran Serçe, a.g.e., s. 37.

${ }^{45}$ Kasaba, a.g.e., s. 94-95. Yerasimos’un ifadesi ile “... büyük servetlerin ortaya çıkışına ve Türk burjuvazisinin üyeleri arasında ilk olarak önemli bir sermaye birikiminin oluşmasına iște bu dönemde tanık oluruz" (Yerasimos, a.g.e., s. 625).

${ }^{46}$ Tarı Zafer Tunaya, Türkiye'de Siyasal Partiler -İkinci Meşrutiyet Dönemi-, İletişim Yayınları, İstanbul, 1998, s. 443-444. 
değil, İttihat ve Terakki'nin uyguladığ 1 'milli iktisat' siyasetinin doğal bir uzantısıdır ${ }^{47}$. Bunun doğal yansıması da bu halka doğru gitme yöneliminin söz konusu yeni orta sınıfın hassasiyetlerine göre biçimlenmesidir. $\mathrm{Bu}$ anlamda Halka Doğru Cemiyeti çerçevesinde halka doğru gidenler, "bu kez, Türk Ocakları'nın Anadolu'ya yönelik Narodnik eğilimlerin ötesinde, Müslüman-Türk unsurun, özellikle dış odaklara karşı, ekonomik çıkar birliğini gözetiyorlardı. 'Halka Doğru' hareketi artık bir 'orta sınıf' hareketiydi; maddi tabanı vardı; ekonomik çıkarlarla kültürel oluşumu aynı potada eritmeyi amaçlıyordu. İttihatçılar, bundan böyle halkçıydılar; Anadolu eşrafiyla bütünleşiyor, Anadolu'da 'ulusal pazar' oluşturmanın gereğine inanıyorlardı. Bu nedenle ulusçulukla halkçılığın eşgüdümlenmesi gerekiyordu" ". Tunaya'nın da belirttiğine göre Cemiyet "Türkçülük ideolojisine, halkçı bir unsur eklemiştir"49. Yani Halka Doğru Cemiyeti temelde burjuvazinin ilerici aşamasının ideolojisi olan ulusçuluğa (Türkiye özelinde Türkçülüğe), bu aşamanın gereği olarak diğer ezilen halk kesimleri ile kuracağı ilerici ittifak (ulusal pazarın inşası=ulusal bağımsızlığın kazanılması) çerçevesinde doğal olarak halkçı bir öz vermeye çalışmıştır. Ancak bu demek değildir ki anılan hareketin halkçılığ halkın alt tabakalarına yaslanmaktadır. Halka Doğru Cemiyeti'nin halktan anladığı, İttihat ve Terakki'nin Anadolu eşrafiyla bütünleşmesi anlamında, orta sınıflardı5 ${ }^{50}$. Dolayısıyla Cemiyet'in halkçılı̆̆ kendi burjuvazisini kendi yerel değerlerinden hareketle yaratmak ve gönendirmek üzerine inşa edilmiştir. $\mathrm{Bu}$ anlamda temelde ulusçuluk ile harmanlanmış bir halkçılık anlayışıdır -ki bu yönüyle Meşrutiyet Halkçılı̆̆ı'nın genel bir görünümünü sergiler.

Cemiyet söz konusu halkçılık anlayışını yaymak amacıyla 1 Şubat 1919'da sorumlu müdürlüğünü Celâl Bey'in yaptığı, on beş günde bir çıan ve dönemin iktidarının baskıları nedeniyle sadece dört sayı yayın yapabilen, Halka Doğru Dergisi'ni çıkarmaya başlamıştır. Halka Doğru'nun ilk sayısında "Mecmuamız ancak Türk milletinin orta sınıf tabakasına milli benlik ve içtimai varlığını duyurmayı gaye edinmiş bir hars mecmuasıdır; siyasi maksat ve neşriyattan külliyen âridir" denilmekteydi ${ }^{51}$. Bu ifadede de görüldüğü üzere Cemiyet'in amacı, orta sınıfa/burjuvaziye bir milli benlik kazandırmaktır ve bunun en doğru yolu da halkın kültürüne inmek ve oradan

\footnotetext{
${ }^{47}$ Toprak, a.g.e., s. 49.

${ }^{48}$ Toprak, a.g.e., s. 51.

${ }^{49}$ Tunaya, a.g.e., s. 444.

${ }^{50}$ Karaömerlioğlu, a.g.e., s. 274.

${ }^{51}$ Arıkan, a.g.e., s. 109-110.
} 
alınan öz, yalın kültür ile bir milli benlik yaratmaktır. Bu da doğal olarak halka doğru gitmekle olacaktı.

II. Meşrutiyet Halkçılığı'nın üçüncü yönelimi ise Akçura Halkçılığı'dır. Bir Tatar Türkü olan Yusuf Akçura "zengin, girişimci, eğitimli, Panslavizm tehdidine karşı koyabilmek için modernleşmeye ve güçlendirmeye çalıştı̆̆ 1 dinsel ve kültürel geleneklerine bağlı bir büyük burjuvazi”nin bulunduğu bir ortamda doğmuş, 1905 Devrimi'nde yıllarca Rusya'da kalmış, öğrenimini Fransa'da tamamlamış, Rusya'daki Türk halklarının davasını önce İtilaf Devletleri, sonra tarafsizlar (Lozan Konferans1, Haziran 1916) ve Rus sosyalistleri nezdinde savunmakla uğraşmış, Panislavizm ve Rus halkçıllığından etkilenerek II. Meşrutiyet'le birlikte uluslaşma sürecinde gündeme gelen Türkçülük ve Halkçılık akımlarında etkin rol oynamış ve derindeki güçleri keşfetmeye, tarihin büyük akıntılarını bulup çıkarmaya, tarihin anlamını ortaya koymaya çalışmış bir aydındı5 ${ }^{52}$.

Akçura söz konusu birikimi ile henüz 1904 y1lında o gün için gündemde olan 'devleti kurtarma' yolları olarak Osmanlıcığ 1 ve İslamcılığ eleştirmiş ve "duygudan çok mantığa seslenerek" her ikisinin de geçersizliğini ortaya koymak suretiyle Osmanlıları "yeni bir politika seçimine ikna etmek" istemiştir ${ }^{53}$. Akşin'in de belirttiği gibi Akçura Üç Tarz-1 Siyaset ile "bir tercih belirtmese de, Türkçülügüü de bir siyaset olabileceğini”" dile getirmiştir" ${ }^{54}$. Ancak her ne kadar Georgeon'un ifadesi ile "bir Türk milliyetçiliği manifestosu" ${ }^{25}$ olarak kendisinden bekleneceği şekilde Türkçülüğü güçlü bir tercih olarak ortaya koymamış olsa da ${ }^{56}$, Üç Tarz-1 Siyaset ile birlikte Akçura "Türkçülüğü devleti kurtarma yollarından birisi olarak sistemli bir şekilde ortaya koymuştur" "57. Çünkü Akçura, Berkes'in belirttiği gibi Osmanlı'da “Türk olmayan 'anasır'ın uluslaşma eğilimleri

${ }^{52}$ François Georgeon, Osmanlı-Türk Modernleşmesi (1900-1930), Çev. Ali Berktay, Yapı Kredi Yayınları, İstanbul, 2006, s. 92-94; Toprak, a.g.e., s. 41.

${ }^{53}$ Georgeon, 2005, s. 34.

${ }^{54}$ Akşin, a.g.e., s. 373.

${ }^{55}$ Georgeon, 2005, s. 34.

${ }^{56}$ Georgeon, Akçura'nın Osmanlıcılık ve İslamcılığı gerçeklikten yoksun oluşları nedeniyle mahkum ettiği makalesinde Türkçülüğü güçlü bir şekilde savunmayışını şöyle ifade eder: "Bir Türk milliyetçiliği manifestosu olan Ǘç Tarz-1 Siyaset’ten doğal olarak beklenen, Türk halkının niteliklerinin yüceltilmesi, kökenlerinin, ne kadar büyük bir uygarlık temeline sahip olduğunun kanıtlanmaya çalışılması, nasıl birlik içinde olduklarının gösterilmek istenmesi gibi şeylerdir. Ama metin böyle değildi! Akıl yürüten ve sonuçlar çıkartan bu aydının arkasında hesap kitap yapan bir iş adamını, öngörülerde bulunan bir burjuvayı görmemek mümkün mü?" (Georgeon, 2005, s. 34).

${ }^{57}$ Kemal Şenoğlu, Yusuf Akçura -Kemalizmin İdeoloğu-, Kaynak Yayınları, İstanbul, 2009, s. 21. 
arasındaki paralelliği ilk gören kişi” olmuştur ${ }^{58}$. Bu nedenle de Osmanlıcılı̆̆ ve İslamc1lığı henüz Meşrutiyet öncesinde gerçekleşmesi imkânsız düşünceler olarak mahkum etmiş ve Balkan uluslarının tuttuğu uluslaşma yolunun Osmanlı'nın kurtuluşu için tek doğru yol olduğu sonucuna varmıştır.

$\mathrm{Bu}$ anlamda “Türkiye'de Türk ulusçuluğunun geleceğini Gökalp’ten çok önce kavrayan" Akçura, devletin ayakta kalabilmesi için bir ulusal devlet olarak yeniden yapılanması gerektiği sonucuna varmıştı5 ${ }^{59}$. Dolayısıyla bu yolda izlenecek siyaset de Türkçülük olacaktır. Akçura'ya göre "Türk ulusal düşüncesinin [Türkçülük] ortaya çıkışı temel bir sosyoekonomik değişimi yansıtmaktadır; bu hareket, kendine bir ulusal pazar oluşturmak ve siyasi özerkliğini fethetmek isteyen Türk burjuvazisinin oluşumuna koşut olarak ortaya çıkmıştır" ${ }^{\prime 60}$. Yani Türkçülük maddi temelleri olan gerçekçi bir seçenektir ve "kendine bir ulusal pazar oluşturmak ve siyasi özerkliğini fethetmek isteyen" bir burjuva sınıfına yaslandığı için de temelde antiemperyalist bir siyasettir ${ }^{61}$. Kald1 ki Akçura da ulusal bir burjuvaziye dayandırdığı Türkçülüğün emperyalist değil, Türkler için talep ettiği millet olma hakkını diğer milletlere de aynı derecede hak olarak tanıyan, gasp edilen hakkı almaya, gasp edilmek istenilen hakkı müdafaaya çalışan demokratik bir milliyetçilik olduğunun altını çizmektedir ${ }^{62}$.

Sonuç olarak Akçura, Meşrutiyet aydınının önüne Türkçülüğü bir kurtuluş programı olarak koymuştur. Ve bu kurtuluş programının dayanacağı ittifak siyaseti de ona göre halkçlıktır. Akçura'ya göre:

"Derin menbaaları iktisadi olan bu iki kuvvetli fikir cereyanı, siyasi bir gayeye vasıl olur ki o da bir milletin, bir halkın mümkünse heyet-i umumiyesinin, değilse ekseriyet-i azimesinin kendi mukadderatına bizzat hâkim olmasıdır; milliyetçilik ve halkçılığın hedef-i aslisi, bila-kayd u şart hâkimiyet-i milliyedir" ${ }^{\circ 3}$.

\footnotetext{
${ }^{58}$ Niyazi Berkes, "Unutulan Adam Yusuf Akçura”, Türk Düşünce Ufukları: Yusuf Akçura, Der. Orhan Çakmak-Atilla Yücel, Alternatif Yayınları, İstanbul, 2002b, s. 197.

${ }^{59}$ Berkes, 2002b ,s. 197.

${ }^{60}$ Georgeon, 2006, s. 95. Akçura'ya göre "ulus toplumlarında asıl güç ve siyasal kalkınma desteği, dayanak noktası 1rk, halk, köylü, esnaf, hatta devlet değil, sınıftır. Hem de burjuva sinifi" (Berkes, 2002b, s. 201).

61 “Akçura'nın milliyetçiliği, esas olarak yabancı ve Batılı tehdide karşı direniş ruhundan beslenmektedir" (Georgeon, 2006, s. 97).

${ }^{62}$ Yusuf Akçura, "Cihan Harbine İștirakimiz ve İstikbalimiz", Siyaset ve İktisat, Yay. Haz. Erdoğan Mura, Sinemis Yayınları, Ankara, 2006b, s. 7-8.

${ }^{63}$ Yusuf Akçura, "Milliyetçilik, Halkçılık”, Siyaset ve İktisat, Yay. Haz. Erdoğan Mura, Sinemis Yayınları, Ankara, 2006c, s. 113.
} 
Dolayısıyla Akçura'ya göre halkçılık ve milliyetçiliğin asli hedefi milli hâkimiyettir. Millet hâkimiyeti için, "milleti yüceltmek amacıyla halkın yüceltilmesi" "64 gereklidir. $\mathrm{Bu}$ anlamda Akçura'nın halktan anladığ 1 "köylülükte yaşayan az toprak sahibi, yahut büsbütün topraksız rençberler; sonra şehirlerde geçinen ufak esnaf ve günlükçü ameleler, 1rgatlar"ken ${ }^{65}$, halkın en önemli sorunları ekonomik sorunlar ve ona bağlı olarak oluşan sağlık sorunları olduğu için de halka doğru gitmek, "emekçi sınıflara tıp, okul, refah götürerek, yardımlaşma ve hayırseverlik kurumlarını geliştirerek onların maddi ve manevi sefaletini azaltmak anlamına gelir'"66. Halkın sorunlarını çözebilmesi için köylü ve esnafın, mektepler, cemiyetler yapabilmesi gerekir ve bunun için de halkın önüne düşüp yol gösterecek okumuş adamlara ihtiyaç vard ${ }^{67}$. Ancak bu tek taraflı olarak halk1 seven okumuşların halka gitmesi, onun içine karışarak, birlikte yaşayarak sorunlarını öğrenmeye çalışması ile olamaz. Halkın da pasif kalmaması, biraz da onun okumuşlarla yanaşması ve aydınlara sorular sorarak, mektuplar yazarak yardım etmesi gerekmektedir ${ }^{68}$.

Diğer taraftan Akçura, Gökalp'in altıncı aşamada ortadan kalkacaklarını belirttiği toplumsal sınıfların varlı̆gını kabul eder. Ona göre Türkiye'de asıl mevcut sınıflar, "küęük mülk sahibi köylü zerra (ziraatçılar), orta ve büyük çiftlik sahipleri, şehr-i esnaf ve tüccarıdır (küçük ve orta sanayi ve ticaret erbabı)"69. Bu anlamda Akçura'nın toplumsal sınıfların varlığını kabul eden anlayışı çerçevesinde halkçılıktan anladığı da çoğulculuk anlamına gelecek şekilde "Fransızca'daki populisme değil, demokratisme"dir". Ancak Akçura'nın toplumsal sınıfların varlığını kabul etmesi, bu sınıflardan birisinin diğerleri üzerindeki hâkimiyetini kabul ettiği, onayladığı anlamına gelmez. Ona göre "hâkimiyet-i milliyesine tamamen sahip olan bir kavim diğer milletlere karşı tamamen hür ve müstakil olduğu gibi kendi içinden ayrılan fertlerin veya sınıfların da mahkumu olmaz" "71. Bu çerçevede Akçura, halkçılığın uygulamasını toprak reformunda bulur. Ona göre milli hâkimiyete dayanan bir devletin, yani modern bir devletin kurulabilmesi için

\footnotetext{
64 Akçura'nın "Halka Doğru Cemiyeti” (Türk Yurdu, XIII/9, 1918) başlıklı yazısından aktaran Mehmet Ulusoy, "Türkçülüğün ve Halkçılı̆̆ın Seçkin Kuramcısı Yusuf Akçura", Teori Dergisi, (Haziran 2006), s. 74.

${ }^{65}$ Akçura 1913'ten aktaran Odabaş1, 2005, s. 24.

${ }^{66}$ Georgeon, 2006, s. 100.

${ }^{67}$ Toprak, a.g.e., s. 43.

${ }^{68}$ Odabaş1, 2005, s. 25.

${ }^{69}$ Yusuf Akçura, "İktisadiyat ve Fırkalar", Siyaset ve İktisat, Yay. Haz. Erdoğan Mura, Sinemis Yayınları, Ankara, 2006d, s. 99.

${ }^{70}$ Georgeon, 2005, s. 132.

${ }^{71}$ Akçura, 2006c, s. 113.
} 
buna muhalefet eden, karşı duran iki gerici toplumsal sınıf olarak feodaller ile yobazların ortadan kaldırılması gerekir. Bu iki gerici güç ortadan kaldırılırsa, küçük toprak sahibi köylülük ile ulusal burjuvazi gibi iki ilerleme yanlıs1 güce dayanan Batılı anlamda modern bir devlet kurulabilecektir $^{72}$. Sonuç olarak Akçura'nın halkçılıktan anladığı, gerici toplumsal sınıfların ilerici toplumsal sinıflar olan küçük köylülük ve ulusal burjuvazi tarafindan bertaraf edilmesi ve burjuvazinin önderliğinde/yönetiminde gerçek anlamda demokratik, halka dayalı bir yönetimin kurulmasıdır.

\section{Meşrutiyet Halkçılığı'nın Kemalist Halkçılığa Etkileri}

II. Meşrutiyet Dönemi'nde üç ana yönelim üzerinden geliştiğini saptadığımız halkçılık, Ulusal Kurtuluş Savaşı Dönemi'nden itibaren Kemalist Halkçıllğa etki etmiş ve belli açılardan onu etkilemiştir. Ancak bu etkileme-etkilenme noktalarına değinmeden önce, Kemalist Halkçılığın içeriğinin ne olduğunu ortaya koymak gerekmektedir. Bu ise daha çok bizzat hareketin önderi olarak Mustafa Kemal'in bu konudaki ifadeleri ve yine Cumhuriyet Halk Partisi'nin bu konudaki kararları/kabulleri üzerinden incelenmelidir $^{73}$. Böylece anılan önemli ifadeler ve kararlara değinilerek Kemalist Halkçılık anlayışının genel çerçevesi çizilirken, yeri geldikçe Kemalist Halkçılığın Meşrutiyet Halkçılığı'nın hangi yöneliminden etkilendiğine de değinilerek etkileme-etkilenme noktaları netleştirilmiş olacaktır.

Çetin Altan Atatürk'ün Sosyal Görüşleri adlı eserinde, “Atatürk’te uç veren sosyal görüşler daima aynı hedefe doğru uzanmaktadır. Halkın sömürülmemesine" 74 derken, Emin Türk Eliçin de Mustafa Kemal'in 13 Eylül 1920'de Büyük Millet Meclisine sunduğu Halkçılık Programı'ndan hareketle "Demek ki, Kurtuluş Savaşı'nın en bunalgan günlerinde bile liderin bir halk ve halkçılık anlayışı vardı ve bunun yeni Türkiye devletinin temel yasasına mâl olmasın istiyordu" tespitinde bulunmakta ${ }^{75}$ ve Sabahattin Selek ise Anadolu Ihtilali adlı yapıtında yeni Türk Devleti'nin

\footnotetext{
${ }^{72}$ Georgeon, 2005, s. 133-134.

${ }^{73}$ Halkçılığın anlayış düzeyinde ne olduğu ile uygulama boyutunda bunun ne denli hayata geçirilebildiği iki farklı konudur. Kemalist Halkçılık da uygulama düzeyinde Halkevleri, Köy Enstitüleri gibi kimi kurumsal yapılar, tarım, ulaşım, sağlı gibi alanlarda yapılan atılımlar, seçim hakkının genelleştirilmesi gibi siyasal yönelimler ile halkçılığı hayata geçirmek için pek çok adım atmıştır. Ancak amaçladığı hedefe ulaşıp ulaşamadığı konusu ayrı bir makalenin konusudur. Bu makalede yalnız düşünsel düzeyde Kemalist Halkçıllığın ne olduğu ve Meşrutiyet Halkçılı̆̆ı'ndan ne oranda ve nasıl etkilendiği inceleme konusu edilmiştir.

${ }_{74}^{74}$ Çetin Altan, Atatürk'ün Sosyal Görüşleri, Dönem Yayınları, İstanbul, 1965, s. 7.

${ }^{75}$ Emin Türk Eliçin, Kemalist Devrim İdeolojisi, Ant Yayınları, İstanbul, 1970, s. 306.
} 
kuruluşundaki temel görüşü halkçılık olarak ortaya koymaktadır ${ }^{76}$. Gerçekten de hareketin liderinin henüz savaş sürerken geliştirdiği ve her firsatta ortaya koyduğu bir halkçılık anlayışı vardır ve bu anlayış kendisini ilk olarak Atatürk'ün Halkçılık Programı'nda belgelemiştir. 18 Eylül 1920 tarihinde Atatürk tarafından Meclis'e sunulan Anayasa Tasarısı niteliğindeki metin Halkçılık Programı olarak anılır ki bu program 20 Ocak 1921 tarihinde de Türkiye Cumhuriyeti'nin ilk Anayasası olarak kabul edilmiştir. Programın sekizinci maddesinde "Türkiye Halk Hükümeti, Büyük Millet Meclisi tarafından idare olunur. Ve 'Türkiye Büyük Millet Meclisi Hükümeti' unvanını taşır" ${ }^{\text {"77 }}$ ifadesine yer verilerek hem yeni devletin adı Türkiye olarak ilk kez anılır hem de bu yeni devletin bir halk hükümeti ile yönetileceği ilân edilmiş olur. Yine Programın ikinci maddesinde de halk hükümetinin görevi şöyle belirtilir:

“Türkiye Büyük Millet Meclisi hükümeti hayat ve bağımsızlığını kurtarmay1 yegâne ve mukaddes gaye bildiği halk1, emperyalizm ve kapitalizm tahakküm ve zulmünden kurtararak irade ve hâkimiyetin hakiki sahibi kılmakla gayesine ulaşacağı inancındadır" ${ }^{, 78}$.

Halkçılık Programı'nda bizzat önderinin tanımlaması ile kendisini bir "halk hükümeti" olarak ifade eden Anadolu Hareketi, hareketin halkçı içeriğini de emperyalizme ve kapitalizme karşı olmak biçiminde belirlemiştir $^{79}$. Yine Mustafa Kemal, Program sonrasında 1 Aralık 1921'de Meclis'te yaptığı bir konuşmasında da hükümetin biçimine dair şunları söylemektedir:

“"Bu hükûmet demokrat bir hükûmet midir, sosyalist bir hükûmet midir, yani şimdiye kadar okuduğumuz kitaplarda ismi söylenen hükûmetlerden hangisidir?' buyurdular! Efendiler bizim hükûmetimiz demokratik bir hükûmet değildir. Sosyalist bir hükûmet değildir. Ve gerçekten kitaplarda var olan hükûmetlerin, bilimsel mahiyeti bakımından, hiçbirine benzemeyen bir hükûmettir. Fakat millî hâkimiyeti, millî irâdeyi oluşturan tek bir hükûmettir, bu öze sahip bir hükûmettir! İlmî ve sosyal noktadan bizim hükûmetimizi ifade etmek gerekirse "halk hükûmeti" deriz... Fakat meslekî çalışma bakımından bile düşündüğümüz zaman, biz hayatını, istiklâlini

\footnotetext{
${ }^{76}$ Sabahattin Selek, Anadolu İhtilâli, Burçak Yayınları, İstanbul, 1968, s. 487.

${ }^{77}$ Atatürk'ün Bütün Eserleri, Cilt 9, Kaynak Yayınları, İstanbul, 2006, s. 324.

${ }^{78}$ Atatürk'ün Bütün Eserleri, Cilt 9, s. 324.

79 Tasarı Meclis’te görüşülürken bir milletvekili, emperyalizm ve kapitalizmin zulmünden kurtulma konusu ile ilgili sorusuna, İsmail Suphi Soysallı şu cevabı vermiştir: "Biz, genel olarak emperyalizm aleyhineyiz. Emperyalizm nereden gelirse gelsin. Kendimiz emperyalist değiliz ve emperyalistlerin aleti de olamayı. Kapitalizm meselesine gelince; kapitalizm zulmü nerede cari olursa olsun aleyhindeyiz" (Selek, a.g.e., s. 489).
} 
kurtarmak için çalışan at uşağı sahipleri, zavallı bir halkız! Konumumuzu bilelim. Kurtulmak, yaşamak için çalışan ve çalışmaya mecbur olan bir halkız! Bundan dolayı her birimizin hakkı vardır. Yetkisi vardır. Fakat çalışmak sayesinde bir hakkı kazanırız. Yoksa arka üstü yatmak ve hayatını çalışmaktan arınmış geçirmek isteyen insanların bizim toplumumuz içerisinde yeri yoktur, hakkı yoktur! O halde ifade edelim ki Efendiler! Halkçılık, sosyal düzenini çalışmasına, hukukuna dayandırmak isteyen bir meslekî çalışmadır",

Mustafa Kemal bu konuşmasında hükümet biçiminin bir halk hükümeti olduğuna tekrar değinmekle birlikte, halk ve halkçılıktan da ne anladığını ortaya koymuştur. Ona göre halk hayatını ve bağımsızlı̆ıını kurtarmak için çalışan emekçilerin bütünüyken, halkçılık da toplumsal düzenini çalışma ve hukuk (adalet, eşitlik) üzerine bina eden bir toplumsal öğretidir. Halkçılığı hukuksal boyutta, yani adalet önünde eşitlik olarak değerlendiren bu yönü ile Kemalist Halkçı1ık, Gökalp'in halkçılık anlayışına yaklaşır ve bu anlamda ondan izler taşır. Ki her iki yaklaşım da ulus yaratma sürecinin halkı oluşturan yurttaşları hukuksal düzeyde eşitleyen görüşünün bir görünümü niteliğindedir.

Programdan sonra 8 Nisan 1923'te yine Mustafa Kemal tarafindan Müdafaa-i Hukuk Grubu'nun seçim bildirgesi olarak kaleme alınan ve Dokuz Umde (İlke) olarak bilinen kararlar da halkçılık düşüncesinin güçlü bir görünümüdür. Öyle ki bu ilkeler ile köylünün o gün için görünür olan pek çok sorununun çözümüne değinilmiş ${ }^{81}$, ulaşım sorununa demiryolu ile çözüm üretileceği belirtilmiş, genel sağlik sorunları için kuruluşların kurulacağ 1 ve işçileri koruyucu yasaların çıkartılacağı belirtilmiş ve son olarak özel girişimciliğe de değinilerek işbirliğine dayanması arzu edilen halkın bütün bileşenlerine ayrım gözetilmeden seslenilmiştir ${ }^{82}$. Ancak yine

\footnotetext{
${ }^{80}$ Atatürk'ün Söylev ve Demeçleri, Bakanlar Kurulu'nun Görev ve Yetkisini Belirten Kanun Teklifi Dolayısılyla, 01.12.1921, http://www.atam.gov.tr/index.php?Page=SoylevDemecler\&IcerikNo=83, erişim: 20.04.2011. ${ }^{81} \mathrm{Bu}$ konuda toplam altı madde bulunmaktadır: 1- Halkın aşar vergisiyle ilgili yakınmaları, uğradığı haksızlıklar düzeltilecektir, 2- Tütün ekim ve ticareti için ulusal yararlara uygun önlemler alınacaktır, 3- Parasal kuruluşlar, bankalar çiftçi, sanayici, tüccar ve bütün çalışanlara kolay kredi sağlayacak biçimde düzeltilecek ve çoğaltılacaktır, 4- Ziraat Bankası'nın varolan anaparası arttırılacak, çiftçilere daha kolaylıkla ve daha çok yardım yapılması sağlanacaktır, 5- Ülke tarımını geliştirmek için tarım makineleri dışalım yoluyla getirilecek ve çiftçiler bu makinelerden kolaylıkla yararlandırılacaktır, 6- Ham maddesi ülkede bulunan malların üretimi için gerekli önlemler alınacak ve bu üretimi yapanlar korunacak, verilecek ödüllerle desteklenecektir (Suna Kili, Atatürk Devrimi, Türkiye İş Bankası Yayınları, İstanbul, 1981, s. 153-154).

${ }^{82}$ Kili, a.g.e., s. $153-154$.
} 
de ilkelerin bütünü dikkate alındığında bir tarım ülkesi olan Türkiye'de dokuz ilkeden en ayrıntılı işlenmiş olanın köylülüğün sorunlarını çözmek üzere biçimlendirildiğ ${ }^{83}$ ve bu anlamda "köylü, milletin efendisidir" ifadesinin bu ilkede vücut bulduğu söylenebilir. Dolayısıyla Kemalist Halkçılık başlarda her ne kadar ulus yaratma saiki ile halkın tüm kesimlerine seslenmeyi bir gereklilik olarak görse de, Dokuz Umde'nin içeriğine bakılarak rahatlıkla söylenebilir ki, Akçura'nın köylülüğü temel alan halk anlayışına çok daha yakın bir duruş sergiler. Tıpkı Atatürk'ün 1 Mart 1922'deki konuşmasına “Türkiye'nin gerçek sahibi ve efendisi, gerçek üretici olan köylüdür" biçiminde yansıdığı gibi ${ }^{84}$.

Cumhuriyet Halk Fırkası'nın 9 Eylül 1923 tarihli Tüzüğü’nün birinci maddesinde de Fırka'nın amacı "milli hâkimiyetin halk tarafından ve halk için icrasına rehberlik etmek" olarak belirtildikten sonra ${ }^{85}$, ikinci maddesinde halk kavramına ve halkçılığın ne olduğuna açıklık getirilir. Fırkanın tanımına göre:

"Fırka nazarında halk kavramı, herhangi bir sınıfla sınırlı değildir. Hiçbir imtiyaz iddiasında bulunmayan ve genel olarak kanun karşısında mutlak bir eşitliği kabul eden bütün fertler halktandır. Halkçılar, hiçbir ailenin, hiçbir sınıfın, hiçbir cemaatin, hiçbir ferdin imtiyazlarını kabul etmeyen ve kanunları koymaktaki mutlak hürriyet ve bağımsızlığı tanıyan fertlerdir" ${ }^{\prime 86}$.

83 İlke 5: 1. Aşar usulünde halkın yakındığı ve zarar gördüğü noktalar temelden düzeltilmelidir. 2. Tütün tarım ve ticaretinde ulusun yararına uygun biçiminde önlem alınacaktır. 3. Mali kurumlar çiftçilere, sanayici ve tüccarlara ve bütün diğer iş adamlarına kolaylıkla borç verecek durumda düzenlenecek ve çoğaltılacaktır. 4. Ziraat Bankası'nın sermayesi arttırılacak, çiftçilere daha kolay ve daha geniş yardım edilebilmesi sağlanacaktır. 5. Ülkemiz çiftçiliği için tarım makineleri geniş ölçüde yurt dışından getirilecek ve çiftçilerimizin tarım araç ve gereçlerinden kolaylıkla yararlanabilmeleri sağlanacaktır. 6. Ham maddeleri ülkemizden bulunan mal ve sanat ürünlerinin ülke içinde yapılabilmesini, koruma ve teşvikte bulunulması ve ödüller verilmesi için her türlü önlem alınacaktır. 7. Hemen gereksinme duyduğumuz demiryolları için gerekli girişimler ve uygulamalar yapılacaktır. 8 . İlköğretimde, öğretimin birleştirilmesi ve bütün okullarımızın gereksinmelerimize ve çağdaş temellere oturtulması öğretmen ve profesörlerimizin hizmetlerinde yükselmeleri ve ilerlemeleri sağlanacaktır. 9. Genel sağlık ve sosyal yardımla ilgili kurumlar düzeltilip çoğaltılacak, çalışanları için koruyucu yasalar yapılacaktır. 10. Ormanlarımızdan bilimin gelişmesine uygun biçimde yararlanmayı, madenlerimizin en verimli biçimde işletilmesi ve hayvanlarımızın soylarının iyileştirilip çoğaltılmasını sağlayacak esaslar konulacaktır.

${ }^{84}$ Atatürk'ün Söylev ve Demeçleri, Türkiye Büyük Millet Meclisi’nin Üçüncü Toplanma Yilını Açarken, 01.03.1922, http://www.atam.gov.tr/index.php?Page=SoylevDemecler\&IcerikNo=93, erişim: 20.04.2011.

${ }_{85}^{85}$ Atatürk'ün Bütün Eserleri, Cilt 16, Kaynak Yayınları, İstanbul, 2005, s. 100.

${ }^{86}$ Atatürk'ün Bütün Eserleri, Cilt 16, s. 100. 
Benzer içerikteki tanımlamalar 22 Ekim 1927 tarihli Cumhuriyet Halk Fırkası Tüzüğü'nün dördüncü maddesinde ${ }^{87}, 13-14$ Mayıs 1931 tarihli CHF Programı'nda, 1935 Programı ve 1939 Programı için Atatürk'ün 1937 yılında yaptığ $\breve{g}_{1}$ hazırlıklarda da tekrarlanmıştır ${ }^{88}$. Bunlar arasında halkçılık görüşünün asıl biçimlendiği program, 6 Ok'un resmileştiği program olan 1931 Programı'dır. Buradaki halkçılık tanımı da 1923 Tüzüğü’ndeki tanıma yakın bir tanımdır:

"İrade ve hâkimiyet kaynağı millettir. Bu irade ve hâkimiyetin, devletin vatandaşa ve vatandaşın devlete karşılıklı vazifelerinin hakkıyla yapılmasını tanzim yoluyla kullanılması Fırka'ca büyük esastır. Kanunlar önünde mutlak bir eşitlik kabul eden ve hiçbir ferde, hiçbir aileye, hiçbir sınıfa, hiçbir cemaate imtiyaz tanımayan fertleri halktan ve halkçı olarak kabul ederiz.

Türkiye Cumhuriyeti halkını, ayrı ayrı sınıflardan meydana gelmiş değil ve fakat ferdi ve toplumsal hayat için işbölümü itibariyle muhtelif mesai sahiplerine ayrılmış bir camia kabul etmek esas prensiplerimizdendir. AKüçük çiftçiler, B- Küçük sanayi sahipleri ve esnaf, C- Amele ve işçi, ÇSerbest meslek sahipleri, D- Sanayi sahipleri, büyük arazi ve iş sahipleri ve tüccar, Türk camiasını teşkil eden başlıca çalışma zümreleridir. Bunların her birinin çalışması diğerinin ve bütün camianın hayat ve saadeti için zaruridir. Fırkamızın bu prensiple hedeflediği gaye, sınıf mücadelesi yerine toplumsal intizam ve dayanışma temin etmek ve birbirini bozmayacak surette menfaatlerde ahenk tesis eylemektir. Menfaatler kabiliyet ve çalışma derecesiyle orantilı olur" ${ }^{\prime \prime}$.

\footnotetext{
87 "Fırka, milli hakimiyet ve idarenin alakalı olduğu bütün faaliyet şubelerinde halk tarafından ve halk için kaidesini hâkim kılmayı gaye edinmiştir. Kanun nazarında mutlak bir eşitliği kabul eden ve hiçbir ailenin ve hiçbir sınıfın, hiçbir cemaatin, hiçbir ferdin imtiyazlarını tanımayan fertleri halktan ve halkçı olarak kabul eyler" (Atatürk'ün Bütün Eserleri, Cilt 22, Kaynak Yayınları, İstanbul, 2007, s. 22).

88 Anılan Programların tam metni için bkz. Doğu Perinçek, Atatürk'ün CHP Program ve Tüzükleri, Kaynak Yayınları, İstanbul, 2008.

${ }^{89}$ Perinçek, a.g.e., s. 128-130. Atatürk 17 Şubat 1923'te İzmir İktisat Kongresi'nde yaptı̆̆ı konuşmada da halkın çıkarlarının çatışma halinde değil, tam tersine uyum içerisinde olduğunu şu sözlerle ifade eder: "Bence halk dönemi, ekonomi dönemi diye adlandırılmalıdır. Öyle bir ekonomi dönemi ki onda ülkemiz bayındır olsun, ulusumuz gönençli olsun ve zengin olsun" dedikten sonra da "bizim halkımız, çıkarları birbirinden ayrılan sınıflar halinde değil, tersine varlıkları ve çalışmalarının sonuçları birbirlerine gerekli olan sınıflardan oluşur. Bu dakikada dinleyicilerim çiftçilerdir, sanatkârlardır, tüccarlardır ve işçilerdir. Bunların hangisi birbirinin karşıtı olabilir. Çiftçinin sanatkâra, sanatkârın çiftçiye ve çiftçinin tüccara ve bunların hepsine, birbirine ve işçilere gereksinmesi olduğunu kim yadsıyabilir... Gönençli ve kıvançlı olarak çalışmalıdır ve bütün bu saydığımız sınıflar aynı zamanda zengin olmalıdır ve yaşamın gerçek lezzetini tadabilmelidir ki, çalışmak için erk ve güç bulabilsin” (Kili, a.g.e., s. 157160). Ki sınıf çelişkilerinin çok sınırlı olduğu Erken Cumhuriyet Dönemi'nde, üstelik bu dönemin bir ulus inşası süreci olduğu dikkate alındığında bu tespitler yanlış ya da gerçekliğin
} 
Görüldüğü gibi CHF'nin programlaştırdığ 1 ve firkanın ana vasıflarından birisi olarak belirttiği Kemalist Halkçılık anlayışı halkı "bir ulusun kurduğu devlette büyük kalabalığı ortaya getiren, çalışkan ve hemen hepsi üretici olan yurttaşların topluluğu" 90 olarak tanımlarken, halkçıllktan kastı da "ulus arasında bir eşitliği gözetmek"tir" ${ }^{91}$. Dolayısıyla bu anlayış hak, adalet üzerine kurulu bir çalışma düzeni ile birbirine bağlanan, aralarında ayrıcalıkların reddedildiği ve kanun önünde eşitlenen halk bütününün sınıf çatışmaları ile bölünmek yerine işbölümü ve dayanışma ile birbirlerine bağlandığ 1 bir görüşü ifade eder. Ve bu nitelikleri taşıyan halk, hâkimiyetin kaynağını oluşturur -halk hükümeti anlamında. Ki bu yönüyle de Kemalist Halkçılık, Akçura ve Gökalp'in halkçılık anlayışlarının bir sentezi niteliğindedir ${ }^{92}$. Böyle olmakla birlikte Kemalist Halkçılık çoğu zaman Gökalp'in toplumsal sınıfların kalktığı evre olarak belirttiği evreye denk gelen dayanışmacı halkçılık anlayışına yakın bir yönelim olarak tespit edilmiştir. Ancak Kemalist Halkçılık bağlamındaki dayanışmacılık Gökalp dayanışmacılığından çok, Fransız Devrimi'nin Üçüncü Sınıf anlayışına denk düşen bir 'dayanışmacılığı' ve bütünlüğü ifade eder. Ahmad'a göre:

"Bu terimlerin seçkinler arasında aşağılayıcı bir anlam taşıdığı bir sosyal ve siyasal ortamda 'halk' ve 'halkçıllk' terimlerinin kullanılması, başlı başına devrimci bir şeydir. Çünkü Kemalist seçkinlerin önemli bir bölümü için halkçılık, bir siyasi barbarlık biçimi ya da halkın ilerlemeyi durdurmak için kullandığı Luddcu siyasi faaliyet anlamına geliyordu. Ancak onların dilinde 'halk' terimi, Narodniklerin kullanımına göre daha geniştir. $\mathrm{Bu}$ terimin tanımı, modern Türk siyasi düşüncesine olan etkisi henüz incelenmemiş bulunan Fransız Devrimi'nin erken dönemlerindeki 'Üçüncü Sınıf' tanımına daha yakındır. Dolayısıyla 'halk' terimi, çeşitli toplumsal güçlerin eski düzene karşı birliğini çağrıștırmaktaydı. Bu birliğin başlıca görevi, eski düzeni yenilgiye uğratmak, yıkmak ve yeni bir düzen yaratmaktı. Bu görev ise, bu birliğin, yani 'halk'ın bütün unsurları arasında dayanışma beraberliği gerektirdiği için aralarında çıkar çatışmasına (yani sınıf çatışmasına) yer yoktu" ${ }^{\text {"9 }}$.

çarpıtılması da değildir. 1. Dünya Savaşı sırasında hızla zenginleşmekle birlikte nihayetinde sanayici olmayan bir sınırlı tüccar burjuvazi, ona bağlı olarak sınırlı bir iş̧̧i sınıfına karşılık toplumun ezici çoğunluğu kendi küçük mülkiyetinde tarımla geçinmeye çalışan köylülüktür.

${ }^{90}$ Şeref Aykut, Kamâlizm -CHP Programının İzah-, Kaynak Yayınları, İstanbul, 2008, s. 38.

${ }^{91}$ Aykut, a.g.e., s. 38.

92 Hâkimiyet kaynağı olmak ve halkı oluşturan farklı kesimler/sınıflar arasında ayrıcalığın olmaması, birinin diğerine üstün olmaması anlamında Akçura'nın, kanun önünde eșitlik ve sınıf çatışması yerine işbölümü ve dayanışmanın olması anlamında da Gökalp'in izlerini taşır.

${ }_{93}^{93}$ Feroz Ahmad, İttihatçılıktan Kemalizme, Çev. Fatmagül Berktay Baltalı, Kaynak Yayınları, İstanbul, 1999, s. 164 (Vurgu bana aittir). Bu konuda benzer bir tespiti de, Kemalist Halkçılığı 
$\mathrm{Bu}$ anlamda Kemalist Halkçılığın temelindeki dayanışma ve işbölümü anlayışı, temel olarak ulusu ve ona dayanan ulusal devleti yaratmak için halkın tüm ilerici güçlerinin (köylülük ve ulusal burjuvazi) eski düzenin temsilcisi olan tüm gerici güçlere karşı antiemperyalizm temelinde işbirliği yapması ve ortak amaç yolunda dayanışma içinde çalışması anlamına gelir. Ki bu anlamda küçük mülk sahibi köylülük ile birleşen ulusal bir burjuvazi önderliğinde yürütülecek olan uluslaşma sürecinin dayanacağ ittifak siyaseti bağlamında Kemalist Halkçılık Akçura Halkçılığı'ndan güçlü izler taşır.

\section{Sonuç}

Kemalist Halkçılık, Rus Narodnik Akımı'ndan köklerini alan Meşrutiyet Halkçılığı'nın birikimi üzerinde yükselmiş ve onun özellikle Gökalp ve Akçura yönelimlerinden önemli ölçüde etkilenmiş, onlardan güçlü izler taşımıştır. Bu anlamda Gökalp Kemalist Halkçılığı özellikle halkı adalet önünde eşit olan insanlardan kurulu bir bütün olarak değerlendiren görüşleri ile etkilerken, Akçura da ulusal kurtuluş savaşını ve ardından kurduğu ulusal devletini köylülük ve ulusal burjuvaziden kurulu bir halk temeline dayandıran Kemalist düşünceye bu yönden etki etmiştir. Kaldı ki söz konusu etkilerin CHF programlarında ortaya konulan hak, adalet üzerine kurulu bir çalışma düzeni ile birbirine bağlanan, aralarında ayrıcalıkların reddedildiği ve kanun önünde eşitlenen, sınıf çatışmaları ile bölünmek yerine işbölümü ve dayanışma ile birbirlerine bağlanan bir halk ve bunun üzerinde yükselen halkçılık anlayışları çerçevesinde sentezlendiği de görülmektedir.

Kemalist Halkçılığın Meşrutiyet Halkçılığı'nın Gökalp ve Akçura olmak üzere iki önemli kanadından taşıdığı bu izler, aynı oranda da Fransız Devrimi'nin Üçüncü Sınıf anlayışına yaklaşan halk ve ulusal birlik-bütünlük anlamındaki dayanışma anlayışı ile harmanlanarak yeni ve kendine özgü bir halkçı1ık anlayışı olarak belirmiştir. Bu anlamda Kemalist Halkçılık, ulus ve ulus devlet inşası sürecinin dayandığı en temel ittifak siyaseti olarak belirmiştir. Halka Doğru Derneği Halkçılığı ise halk1 yalnız orta sınıf/burjuvazi ile sınırlaması ve kendi yerel değerlerinden hareketle kendi

ulus inşası sürecinin halk arasında olmazsa olmaz birliktelik ve bütünlük mantığı ile birlikte değerlendiren Karaömerlioğlu yapmaktadır. Ona göre de: "Egemenliğin meşru kaynağının bir hanedan ya da dinsel bir simgede olmadığı durumlarda, millete ve halka dayanan bir anlayış haliyle tek ve bölünmez, içerisinde tezatların, sınıfların, farkların minimuma indirgendiği bir halk ve millet kavramına da ihtiyaç duyar. İşte Cumhuriyet ile gündeme gelen 'sınıfsız, kaynaşış bir kitleyiz' şiarını bu anlamda tarihsel bağlamına oturtmak gerekir. Dolayısıyla, genel kanının aksine, Türkiye'de 'sınıfsız, kaynaşmıș kitleye' vurgu sınıf çatışmasını esas kabul eden sosyalist ya da komünist hareketlerden çok Osmanlı'nın toplumsal ve siyasal yapısına karşı öne çıkarılmış, milliyetçi bir söylemin yapı taşlarından birisiydi" (Karaömerlioğlu, a.g.e., s. 277). 
burjuvazisini yaratarak ona milli bir benlik kazandırma anlamındaki halkçı1lık anlayışı nedeniyle, Kemalist Halkçı1lığın şekillenmesine herhangi bir etkide bulunamamıştır.

\section{Kaynakça}

Ahmad, Feroz; İttihatçılıktan Kemalizme, Çev. Fatmagül Berktay Baltalı, Kaynak Yayınları, İstanbul, 1999.

Akçura, Yusuf; "İttifak'a Dair", Siyaset ve İktisat, Yay. Haz. Erdoğan Mura, Sinemis Yayınları, Ankara, 2006a, s. 11-20.

Akçura, Yusuf; "Cihan Harbine İştirakimiz ve İstikbalimiz”, Siyaset ve İktisat, Yay. Haz. Erdoğan Mura, Sinemis Yayınları, Ankara, 2006b, 1-10.

Akçura, Yusuf; "Milliyetçilik, Halkçıllk", Siyaset ve İktisat, Yay. Haz. Erdoğan Mura, Sinemis Yayınları, Ankara, 2006c, 113-115.

Akçura, Yusuf; "İktisadiyat ve Fırkalar", Siyaset ve İktisat, Yay. Haz. Erdoğan Mura, Sinemis Yayınları, Ankara, 2006d, 93-100.

Akçura, Yusuf; Üç Tarz-1 Siyaset, Lotus Yayınları, Ankara, 2008.

Akşin, Sina; Jön Türkler ve İttihat ve Terakki, İmge Yayınevi, Ankara, 2001.

Altan, Çetin; Atatürk'ün Sosyal Görüşleri, Dönem Yayınları, İstanbul, 1965.

Arıkan, Zeki; "Tanzimat ve Meşrutiyet Döneminde İzmir Basını", Tanzimat'tan Cumhuriyet'e Türkiye Ansiklopedisi, 1. Cilt, İletişim Yayınları, İstanbul, 1985, s. $103-111$.

Atatürk'ün Bütün Eserleri; Cilt 9, Kaynak Yayınları, İstanbul, 2006.

Atatürk'ün Bütün Eserleri; Cilt 16, Kaynak Yayınları, İstanbul, 2005.

Atatürk'ün Bütün Eserleri; Cilt 22, Kaynak Yayınları, İstanbul, 2007.

Atatürk'ün Söylev ve Demeçleri, "Bakanlar Kurulu'nun Görev ve Yetkisini Belirten Kanun Teklifi Dolayısıla", http://www.atam.gov.tr/index.php?Page=SoylevDemecler\& $\quad$ IcerikNo=83, erişim: 20.04.2011.

Atatürk'ün Söylev ve Demeçleri, “Türkiye Büyük Millet Meclisi’nin Üçüncü Toplanma Yılını Açarken”, 01.03.1922, http://www.atam.gov.tr/index.php?Page=SoylevDemecler\& IcerikNo=93, erişim: 20.04.2011.

Aykut, Şeref; Kamâlizm -CHP Programının İzah-, Kaynak Yayınları, İstanbul, 2008.

Berkes, Niyazi; Batıcılık, Ulusçuluk ve Toplumsal Devrimler, Kaynak Yayınları, İstanbul, 2002a. 
Berkes, Niyazi; “Unutulan Adam Yusuf Akçura”, Türk Düşünce Ufukları: Yusuf Akçura, Der. Orhan Çakmak-Atilla Yücel, Alternatif Yayınları, İstanbul, $2002 b$.

Eliçin, Emin Türk; Kemalist Devrim İdeolojisi, Ant Yayınları, İstanbul, 1970.

Frangakis-Syrett, Elena; "Uluslararası Önem Taşıyan Bir Akdeniz Limanının Gelişimi: Smyrna (1700-1914)”, Çev. Işı1k Ergüden, İzmir 1830-1930 Unutulmuş Bir Kent Mi? -Bir Osmanlı Limanından Hatıralar-, Der. MarieCarmen Smyrnelis, İletişim Yayınları, İstanbul, 2008, s. 27-58.

Georgeon, François; Türk Milliyetçiliğinin Kökenleri: Yusuf Akçura 1876-1935, Çev. Alev Er, Tarih Vakfı Yayınları, İstanbul, 2005.

Georgeon, François; Osmanl1-Türk Modernleşmesi (1900-1930), Çev. Ali Berktay, Yapı Kredi Yayınları, İstanbul, 2006.

Gökalp, Ziya; Türkçülüğün Esasları, Yay. Haz. Kemal Bek, Bordo Siyah Yayınları, İstanbul, 2003.

Gökalp, Ziya; “Halkçılık”, Teori Dergisi, Ocak 2007, s. 56-62.

Heyd, Uriel; Türk Ulusçuluğunun Temelleri, Çev. Kadir Günay, Türkiye Cumhuriyeti Kültür Bakanlığı, Ankara, 2002.

Karaömerlioğlu, M. Asım; “Tek Parti Döneminde Halkçılık”, Modern Türkiye'de Siyasi Düşünce, Cilt-2: Kemalizm, İletişim Yayınları, İstanbul, 2002, s. 272283.

Kasaba, Reşat; Osmanlı İmparatorluğu ve Dünya Ekonomisi, Çev. Kudret Emiroğlu, Belge Yayınları, İstanbul, 1993.

Kaya, Alp Yücel; “19. Yüzyıldan 21. Yüzyıla İzmir Ekonomisinde Süreklilik ve Kırılmalar”, Değişen İzmir'i Anlamak, Der. Deniz YıldırımEvren Haspolat, Phoenix Yayınevi, Ankara, 2010, s. 42-106.

Kili, Suna; Atatürk Devrimi, Türkiye İş Bankası Yayınları, İstanbul, 1981.

Kurmuş, Orhan; Emperyalizmin Türkiye’ye Girişi, Yordam Yayınları, İstanbul, 2008.

Odabaşı, Arda; "2. Meşrutiyet Dönemi Türk Halkçılı̆̆ı ve Halka Doğru Dergisi”, Teori Dergisi, Eylül 2005, s. 9-27.

Odabaş1, Arda; “İlk Türk 'Halka Doğru Gitme' Eylemi ve İk 'Halka Doğru Gidenler'”, Teori Dergisi, Ocak 2007, s. 40-55.

Perinçek, Doğu; Atatürk'ün CHP Program ve Tüzükleri, Kaynak Yayınları, İstanbul, 2008.

Selek, Sabahattin; Anadolu İhtilâli, Burçak Yayınları, İstanbul, 1968. 
Serçe, Erkan; “II. Meşrutiyet Döneminde İzmir”, Değişen İzmir'i Anlamak, Der. Deniz Yıldırım-Evren Haspolat, Phoenix Yayınevi, Ankara, 2010, s. 23-41.

Smyrnelis, Marie-Carmen; “Öndeyiş: Tarihini Arayan Şehir”, Çev. Işsık Ergüden, İzmir 1830-1930 Unutulmuş Bir Kent Mi? -Bir Osmanlı Limanından Hatıralar, Der. Marie-Carmen Smyrnelis, İletişim Yayınları, İstanbul, 2008, s. 9-26.

Şenoğlu, Kemal; Yusuf Akçura -Kemalizmin İdeoloğu-, Kaynak Yayınları, İstanbul, 2009.

Tekeli, İlhan; “Türkiye'de Halkçılık”, Cumhuriyet Dönemi Türkiye Ansiklopedisi, 7. Cilt, İletişim Yayınları, İstanbul, 1983, s.1929-1935.

Toprak, Zafer; “Aydın, Ulus,-Devlet ve Popülizm”, Türk Aydını ve Kimlik Sorunu, Der. Sabahattin Şen, Bağlam Yayınları, İstanbul, 1995, s. 39-81.

Tunaya, Tarık Zafer; Türkiye'de Siyasal Partiler -İkinci Meşrutiyet Dönemi-, İletişim Yayınları, İstanbul, 1998.

Ulusoy, Mehmet; “Türkçülüğün ve Halkçılı̆̆ın Seçkin Kuramcısı Yusuf Akçura”, Teori Dergisi, Haziran 2006, s. 61-80.

Walicki, Andrzej; Rus Düşünce Tarihi -Aydınlanma'dan Marksizme-, Çev. Alaeddin Şenel, İletişim Yayınları, İstanbul, 2009.

Yerasimos, Stefanos; Azgelişmişlik Sürecinde Türkiye -Bizans'tan 1971'e-, Çev. Babür Kuzucu, Gözlem Yayınları, İstanbul, 1980.

Yıldız, Veysel; “Rusya'da Halkçılığın Doğuşu ve Gelişimi”, Teori Dergisi, Eylül 2005, s. 44-48. 